\title{
Section 1983 Municipal Liability and the Doctrine of Respondeat Superior
}

\begin{abstract}
Section 1983 of Title 42 of the United States Code, ${ }^{1}$ as recently interpreted by the Supreme Court in Monell $v$. Department of Social Services, ${ }^{2}$ allows municipalities to be held liable for certain violations of constitutional rights committed by their officers. In so construing the statute, the Court overruled those portions of its earlier decision in Monroe v. Pape ${ }^{3}$ holding that municipalities cannot constitute "persons" under section 1983. The Monell Court, however, stopped short of concluding that municipalities should be held liable for all constitutional violations committed by their officers; it indicated instead that liability should be imposed on municipalities only for violations effected pursuant to "official policy," and declared that the doctrine of respondeat superior ${ }^{5}$ is inapplicable to section 1983 suits against municipalities.

Although the rejection of municipal respondeat superior is likely to become one of the most frequently cited aspects of Monell, ${ }^{6}$ the Court's discussion of the outer bounds of municipal liability is in no way essential to the Monell holding. Since the case involved
\end{abstract}

42 U.S.C. $\$ 1983$ (1976) provides:

Every person who, under color of any statute, ordinance, regulation, custom, or usage, of any State or Territory, subjects, or causes to be subjected, any citizen of the United States or any other person within the jurisdiction thereof to the deprivation of any rights, privileges, or immunities secured by the Constitution and laws, shall be liable to the party injured in an action at law, suit in equity, or other proper proceeding for redress.

2436 U.S. 658 (1978).

365 U.S. 167 (1961).

+436 U.S. at 694.

5 The doctrine allows one party to be held liable for another's actions under certain circumstances; the term is generally used, as it is in this comment, to describe its "most familiar illustration . . . the liability of a master for the torts of his servant in the course of his employment." W. Prosser, HandBook of THR LaW of TORTS \& 69, at 458 (4th ed. 1971). See RestatemENT (SECOND) OF AgENCY $§ 219$ (1) (1958) [hereinafter cited as Restatement]. A servant is broadly defined as "a person employed to perform services in the affairs of another and who with respect to the physical conduct in the performance of the services is subject to the other's control or right to control." RestatzemENT, supra, $\$ 220(1)$. See W. Prosser, supra, $\S 70$, at 460 . The modern view is that the employer may be held liable even for the employee's intentional torts, so long as they were committed in the course of the servant's employment. Id. at 464-67. On the "scope of employment" requirement, see RESTATEMENT, supra, §§ 228-237; on the requirement that the employer have "control" over the employee's actions, see id. $\$ 220$ \& Comment d; W. Prosser, supra, $\S 70$, at 460 .

- See, e.g., Owen v. City of Independence, 589 F.2d 335, 336-37 (8th Cir. 1978), cert. granted, 48 U.S.L.W. 3189 (Oct. 2, 1979) (No. 78-1779); Jones v. City of Memphis, 586 F.2d 622, 624-25 (6th Cir. 1978); Kedra v. City of Philadelphia, 454 F. Supp. 652, 677-78 (E.D. Pa. 1978); The Supreme Court, 1977 Term, 92 HaRv. L. RBv. 57, 320 n.52 (1978). 
a formal municipal policy, the respondeat superior analysis is, as Justice Stevens noted, "merely advisory." It therefore seems appropriate to consider at length the proper standard for municipal liability-that is, which actions of which municipal employees can result in governmental liability-before Monell's dictum becomes accepted doctrine.

This comment examines the propriety of municipal respondeat superior liability. ${ }^{9}$ First, it analyzes the reasons offered by the Monell Court for rejecting respondeat superior in section 1983 actions against municipalities. Then, the comment argues that the purposes and legislative history of the provision demand a scheme of respondeat superior liability. Finally, the comment explores the countervailing concerns of federalism, and considers their impact on such a liability scheme.

\section{Monell: Official Municipal Policy}

In Monell, the plaintiffs, female employees of the New York City Department of Social Services and Board of Education, were forced to take unpaid pregnancy leaves before such leaves were medically necessary. ${ }^{10}$ Contending that the policy was unconstitutional, the employees brought a section 1983 action seeking back pay"

${ }^{7}$ See text and note at note 10 infra. See also 436 U.S. at 694 ("this case unquestionably involves official policy as the moving force").

8436 U.S. at 714 (Stevens, J., concurring in part). Justice Stevens wrote a concurrence for the sole purpose of noting that this and other portions of the opinion were "not necessary to explain the Court's decision."

- The Monell Court expressly left open the question whether municipalities should be awarded any form of immunity under section 1983, though it did indicate that granting an absolute immunity would be inappropriate. Id. at 701. In the analogous area of immunity for executive officials, the Court developed a limited "good faith" defense by relying both on policy arguments-principally, that fear of personal liability would inhibit state officials from taking necessary actions, see Wood v. Strickland, 420 U.S. 308, 319-20 (1975); Scheuer v. Rhodes, 416 U.S. 232, 241-42, 246 (1974)-and on the strong common-law background of executive immunity against which section 1983 was passed, see note 21 infra. Neither of these factors supports the principle of limiting municipal liability however, since making a municipality liable will not undesirably inhibit individual action, and since at the time section 1983 was passed there was no strong common-law tradition of municipal immunity, see text and notes at notes 95-100 infra. This comment will not, however, address the proper scope of municipal immunity. That issue should be resolved shortly when the Court reviews Owen v. City of Independence, 589 F.2d 335 (8th Cir. 1978), cert. granted, 48 U.S.L.W. 3189 (Oct. 2,1979 ) (No. 78-1779) -in which the issue is directly presented.

10 436 U.S. at $660-61,661$ n.2.

"The plaintiffs also sought injunctive and declaratory relief. Id. at 661 . The trial court, although noting that the plaintiffs' constitutional rights had been violated, $394 \mathrm{~F}$. Supp. 853, 855 (S.D.N.Y. 1975), aff'd, 532 F.2d 259 (2d Cir. 1976), rev'd, 436 U.S. 658 (1978), denied the claims because of mootness: the city had changed its policies relating to maternity leaves. 
against the Department and its Commissioner, the Board and its Chancellor, and the city of New York. The relief was denied by the lower courts because the damages would ultimately be paid by the city, ${ }^{12}$ which under Monroe $v$. Pape was not a "person" for purposes of section 1983. The Monell Court, however, after a searching discussion of section 1983's legislative history, overruled Monroe's holding that municipalities could not be liable under the statute. ${ }^{13}$ In the course of this analysis, the Court, speaking through Justice Brennan, articulated the new standard of municipal liability under section 1983:

[I]t is when execution of a government's policy or custom, whether made by its lawmakers or by those whose edicts or acts may fairly be said to represent official policy, inflicts the injury that the government as an entity is responsible under $\S 1983.14$

12394 F. Supp. at 855.

13 436 U.S. at 669 . The Court felt compelled to reconsider Monroe v. Pape because its holding was perceived as inconsistent with an uninterrupted series of Supreme Court cases, beginning with Brown v. Board of Educ., 347 U.S. 483 (1954), which had allowed section 1983 actions against school boards. 436 U.S. at 696. See Cleveland Bd. of Educ. v. LaFleur, 414 U.S. 632, 636 (1974); Keyes v. School Dist. No. 1, 413 U.S. 189 (1973); Swann v. CharlotteMecklenburg Bd. of Educ., 402 U.S. 1 (1971); Tinker v. Des Moines Independent School Dist., 393 U.S. 503, 504 (1969); McNeese v. Board of Educ., 373 U.S. 668, 671 (1963).

Because the claim denied by the Court in Monroe $v$. Pape was actually based on respondeat superior, it has been argued that the broad rationale advanced in that case-that municipalities are not "persons" under the statute-should be disregarded; Monroe and its progeny would therefore be read only as rejecting municipal vicarious liability. See, e.g., Levin, The Section 1983 Municipal Immunity Doctrine, 65 Geo. L.J. 1483 (1977). Cf. Monell, 436 U.S. at 663 n.7 (Monroe upheld "insofar as it holds that the doctrine of respondeat superior is not a basis for rendering municipalities liable"). Under such an analysis, Monell would be a clarification rather than an overruling of Monroe. This approach seems to be at the heart of Justice Powell's concurrence, see id. at 704-14 (Powell, J., concurring), for he suggested that by rejecting respondeat superior, the Court avoided having to overrule any of its prior decisions. Id. at 707, 708-13 (Powell, J., concurring).

On closer scrutiny, however, this approach seems incorrect. To argue that Monroe did not bar all section 1983 actions against municipalities would require accepting the Court's result while rejecting entirely its reasoning. And even if Monroe is given such a strained interpretation, Monell would still require overruling a Supreme Court decision: in City of Kenosha v. Bruno, 412 U.S. 507 (1973), the Court applied the Monroe rationale to hold that a municipal ordinance could not be challenged under section 1983.

Justice Powell sought to downplay the stare decisis implications of overturning City of Kenosha by arguing that, since the issue of municipal immunity was raised by the Court in that case, the holding was owed "somewhat less [than usual] deference." 436 U.S. at 709 n.6 (Powell, J., concurring). That, however, does not seem to reduce significantly the precedential impact of the holding. See id. at 718 (Rehnquist, J., dissenting) (citing landmark cases in which issues were raised by the Court). And, given the nearly universal interpretation of Monroe as barring absolutely suits against local governments, see, e.g., The Supreme Court, 1977 Term, supra note 6 , at 312 n.7, it seems pointless to try to distinguish that case from Monell at this late date.

14436 U.S. at 694. 
The Court's conclusion that respondeat superior is not a permissible basis for section 1983 municipal liability was based on analyses of the statutory language, the legislative history, and a prior interpretation of the provision. ${ }^{15}$ Justice Brennan relied principally on both the absence of any explicit mention of respondeat superior in section $1983,{ }^{16}$ and Congress's rejection of the Sherman amendment, ${ }^{17}$ a companion act to section 1983 , one version of which would have imposed an extreme form of vicarious liability on municipalities. On closer scrutiny, however, the inferences the Court drew from these sources are open to serious question; if anything, the legislative history and prior interpretations of section 1983 seem to support a scheme of municipal respondeat superior liability.

\section{A. The Language of Section 1983}

Section 1983, as originally enacted, created liability for "any person who, under color of any . . . statute . . . shall subject, or cause to be subjected, any person . . . to the deprivation of any rights, privileges, or immunities secured by the Constitution." I8 The Monell Court, focusing on the "subject, or cause to be subjected" language, concluded that Congress meant to foreclose all forms of vicarious liability. Justice Brennan made two points based on the language of the statute. First, he noted that section 1983 "cannot be easily read" to impose vicarious liability. ${ }^{19}$ Presumably, he meant that by explicitly imposing liability on the violator through the "shall subject" phrase, Congress meant implicitly to foreclose vicarious liability. The Court, apparently applying the principle of expressio unius exclusio alterius, then stated that "the fact that Congress did specifically provide that A's tort became B's liability if B 'caused' A to subject another to a tort suggests that Congress did not intend $\$ 1983$ liability to attach where such causation was absent."20

The Court's conclusions, however, seem strained. Its interpretation is essentially one from silence: since the statute makes liable those who "subject, or cause to be subjected," the Court concluded

\footnotetext{
is Id. at 691-94.

16 Id. at 691-92.

${ }^{17}$ Id. at 692 n.57, 693-94.

18 Civil Rights Act of 1871 , ch. $22, \S 1,17$ Stat. 13 (current version at 42 U.S.C. $\S 1983$ (1976)) (emphasis added).

19436 U.S. at 692 .

20 Id. (footnote omitted).
} 
that only those directly responsible for a constitutional tort can be found to violate the provision. Yet in the context of section 1983, the legislative silence seems to cut the other way. As the Court stated in Monroe v. Pape, the section should be "read against the background of tort liability,"21 and part of that common-law background is the idea that corporate bodies-both private and munici$\mathrm{pal}^{22}$-may be made liable through respondeat superior. ${ }^{23}$ Since the Reconstruction Congress apparently passed the legislation with tort concepts in mind, a separate respondeat superior provision would have been unnecessary; just as courts have concluded that Congress meant to incorporate into section 1983 such common-law doctrines as proximate cause ${ }^{24}$ and official immunity 25 -concepts as to which the statute is silent-so respondeat superior could have been intended though unmentioned. Direct and vicarious liability coexisted at common law; Congressmen in 1871 would thus likely have expected a simple declaration of employer liability to embrace rather than exclude respondeat superior. And this seems in fact to have been the congressional intent behind the statute's unadorned language. Senator Thurman, for example, suggested that the statute's silence would not be construed as limiting its scope: rather, "there is no limitation whatsoever upon the terms that are employed [in section 1983], and they are as comprehensive as can be used."26

${ }^{21} 365$ U.S. 167, 187 (1961). Accord, Carey v. Piphus, 435 U.S. 247, 258 n.13 (1978); Imbler v. Pachtman, 424 U.S. 409 , 418 (1976) (" $\$ 1983$ is to be read in harmony with general principles of tort immunities and defenses rather than in derogation of them"); Tenney v. Brandhove, 341 U.S. 367, 376 (1951); Nesmith v. Alford, 318 F.2d 110, 125-26 (5th Cir. 1963), cert. denied, 375 U.S. 975 (1964); Note, Choice of Law Under Section 1983, 37 U. ChI. L. Rev. 494, 507-08 (1970).

The Supreme Court, to avoid impairing the effectiveness of section 1983, has not, however, hesitated to disregard or temper common-law tort principles in construing an otherwise silent statute. For instance, the executive immunity ordered by the common law has been qualified under section 1983 by conditioning protection from liability on good faith. See Wood v. Strickland, 420 U.S. 308 (1975); Scheuer v. Rhodes, 416 U.S. 232 (1974).

22 On the application at common law of respondeat superior principles to municipalities, see text and notes at notes 95-100 infra.

${ }^{23}$ See note 5 supra. Indeed, it is difficult to read any broad significance into the statute's causation language, "[b]ecause the word 'causes' is not a term of art that necessarily precludes vicarious liability." Baskin v. Parker, 602 F.2d 1205, 1213 (5th Cir. 1979) (Rubin, J., concurring in part and dissenting in part).

2 See, e.g., Duncan v. Nelson, 466 F.2d 939, 942-43 (7th Cir. 1972). For a criticism of the court's use of proximate cause, see Nahmod, Section 1983 and the "Background" of T'ort Liability, 50 IND. L.J. 5, 23-25 (1974).

${ }_{25}^{25}$ See, e.g., Imbler v. Pachtman, 424 U.S. 409, 417-19 (1975); Pierson v. Ray, 386 U.S. 547, 554-57 (1967); Tenney v. Brandhove, 341 U.S. 367, 376 (1951).

26 Cong. Globe, 42d Cong., 1st Sess. app. 216-17 (1871) (remarks of Sen. Thurman), quoted in Monell, 436 U.S. at $685 \mathrm{n.45}$ (emphasis omitted). Senator Thurman was an oppo- 
The Court also disregarded another aspect of the statute's common-law tort background: in the nineteenth century, the doctrine of respondeat superior was based, at least in part, on the fiction that "he who acts through another, acts himself." 27 Whether it was the master or his servant who physically committed the tort, the master was legally regarded as the "person" who caused the harm. Indeed, in some jurisdictions one could state a cause of action by pleading the acts of the agent as the acts of the principal. ${ }^{28}$ Given the prevailing fiction that the act of the employee was the act of the employer, the fact that Congress provided liability only for any "person" who "shall subject, or cause to be subjected," need not be read to exclude respondeat superior.

Finally, the Court's linguistic analysis is theoretically as well as historically flawed. The Monell Court rejected respondeat superior by concluding that if an employee "caused" a tort, the "municipality" did not cause it. Such an analysis requires, however, that there be a sharp dichotomy between municipal action on the one hand, and the actions of a municipality's lower-level employees on the other. But since all municipal action is necessarily vicarious-a municipality acts only through its agents ${ }^{29}$ - the courts have been unable to determine in any principled manner just what it is

nent of section 1983. For similar statements by supporters of the statute, see the citations to the congressional debates in Monell, 436 U.S. at 685 n.45. See also text and notes at notes 76-77 infra.

${ }^{27}$ Qui facit per alium facit per se. See, e.g., New Orleans, J. \& Great N.R.R. v. Bailey, 40 Miss. 395, 452-53 (1866) ("the act of the agent is the act of the principal himself . . . an incident which the law has wisely attached to the relation, from its earliest history"); Laugher v. Pointer, 5 B. \& C. 547, 553, 108 Eng. Rep. 204, 207 (K.B. 1826) (master liable for acts "of those whom the law denominates his servants, because such servants represent the master himself, and their acts stand upon the same footing as his own"); 1 W. BLAckSTONE, Commentaries * 432 ("wrong done by the servant is looked upon in law as the wrong of the master himself").

${ }^{28}$ See, e.g., Bennett v. Judson, 21 N.Y. 238, 239-40 (1860) ("The same rule of law which imputes to the principal the fraud of the agent, and makes him answerable for the consequences, justifies the allegation in pleading, that the principal himself committed the wrong”); Holmes, Agency (pt. 2), 5 HARv. L. Rev. 20 (1892). See also J. Story, Commentartes ON THE LAW OF AGENCY § 440, at 502-03, § 453b, at 527 (9th ed. Boston 1882)(1st ed. Boston 1839).

23 See Turpin v. Mailet, 579 F.2d 152, 164 (2d Cir.) (en banc) ("a municipality, of course, can only act through its agents"), vacated and remanded sub nom. City of West Haven v. Turpin, 439 U.S. 974 (1978) (for reconsideration in light of Monell); Adekalu v. New York City, 431 F. Supp. 812,819 (S.D.N.Y. 1977) ("All municipal liability is, in a sense, 'vicarious,' and thus the concept of 'vicariousness' alone-to the extent that it refers merely to whether the municipality acted in its own name or not-is not useful"); Collum v. Yurkovitch, $409 \mathrm{~F}$. Supp. 557, 559 (N.D. Ill. 1975); Williams v. Brown, 398 F. Supp. 155, 159 (N.D. Ill. 1975); Schnapper, Civil Rights Litigation After Monell, 79 Colum. L. Rev. 213, 217 (1979). 
that makes the "municipality itself" responsible for some actions and not for others.30

A more straightforward reading of the statutory language suggests. that it encompasses the essential element of tort liability-causation, either direct ("shall subject") or indirect ("cause to be subjected")-coupled with state action and constitutional harm requirements. A requirement of causation is perfectly compatible with vicarious liability; indeed, at common law causation is required in actions based on respondeat superior, since the employer is liable only for harm caused by an employee acting within the scope of his employment. ${ }^{31}$ And the Supreme Court's own opinions in section 1983 cases seem to interpret the statute as establishing the essential element of tort liability and nothing more. ${ }^{32}$

${ }^{30}$ Several courts have attempted, in the context of actions brought against municipalities both under section 1983 and directly under the Constitution, to define municipal action. One court suggested that action is official when the body responsible for it was "authorized by the municipality to make such decisions." Burt v. Abel, 585 F.2d 613, 617 n.9 (4th Cir. 1978). This, however, fails to explain why the municipality cannot be held liable for the actions of its employees, all of whom have presumably been authorized to do their jobs. It also fails to explain who can issue such authorizations on the municipality's behalf. Another court suggested that the employees who can make a municipality liable are those "high elected or appointed officials, chosen directly or indirectly by the people," who hold "such high municipal office that they can reasonably be held to reflect municipal policy." Adekalu v. New York City, 431 F. Supp. 812, 820 (S.D.N.Y. 1977) (action brought directly under the Constitution). But this definition is circular: a "high" official is one who can act for the municipality. That these courts have had such difficulty in defining municipal action is not surprising, since there has also been confusion over whether municipal liability-under either section 1983 or the Constitution -is predicated on the municipality's having committed the constitutional wrong, or on its having negligently failed to supervise the employee. Compare Turpin v. Mailet, 579 F.2d 152, 165 n.37 (2d Cir.) (en banc) ("The municipality . . . has itself committed a wrong distinct from that of its employee-agent"), vacated and remanded sub nom. City of West Haven v. Turpin, 439 U.S. 974 (1978) (for reconsideration in light of Monell) with Owen v. City of Independence, 589 F.2d 335, 337 (8th Cir. 1978) (harm committed by municipality itself), cert. granted, 48 U.S.L.W. 3189 (Oct. 2, 1979) (No. 78-1779). Consequently, the courts have reached disparate results. Compare Turpin v. Mailet, 579 F.2d 152, 168 (2d Cir.) (en banc) (actions of the local board of police commissioners held to give rise to cause of action against municipality, directly under the Constitution), vacated and remanded sub nom. City of West Haven v. Turpin, 439 U.S. 974 (1978) (for reconsideration in light of Monell) with McDonald v. Illinois, 557 F.2d 596 (7th Cir.) (county not held liable for actions of superintendent of county department of corrections), cert. denied, 434 U.S. 966 (1977).

"See W. Prosser, supra note 5, $\$ 69$, at 458 ("The foundation of the action is still negligence, or other fault, on the part of [the employee].").

${ }_{32}$ For example, while there is no language granting any form of immunity in section 1983, the Court has in effect added common-law immunity doctrines to the statute. See, e.g., Imbler v. Pachtman, 424 U.S. 409, 434 (1976) (White, J., concurring) ("there is no language in 42 U.S.C. $\$ 1983$ extending any immunity to state officials" but "there are certain absolute immunities so firmly rooted in the common law and supported by such strong policy reasons that the Court has been unwilling to infer that Congress meant to abolish them"). 
The Monell Court's reliance on the statutory language thus seems misplaced. It is true, of course, that as a general matter the words of a statute are the starting point in statutory construction. But the language of section 1983 is extraordinarily broad and general. It is for that reason that the courts, almost without exception, have viewed the provision against the legislative and common-law background. Monell's analysis of the statutory language, however, failed to take this into account.

\section{B. The Sherman Amendment}

The majority in Monell believed that, even apart from the language of section 1983, the legislative history of the provision demonstrated that Congress did not intend respondeat superior to form a basis for section 1983 municipal liability. The Court's position was based on Congress's rejection of the Sherman amendment, ${ }^{33}$ a proposed addition to the Civil Rights Act of $1871 .{ }^{34}$ But given the essential differences between the Sherman amendment and respondeat superior liability, it is difficult to draw any firm conclusions about the congressional view of vicarious liability from the amendment's rejection. ${ }^{35}$

33 Senator Sherman offered his amendment as a separate section to be added to the end of the Civil Rights Act of 1871, ch. 22, 17 Stat. 13 (current version at 42 U.S.C. $\$ \S 1983,1985$, 1986 (1976)). Monell, 436 U.S. at 666 (citing Cong. Grobe, 42d Cong., 1st Sess. 663 (1871)). Section one of the Act, which was passed with little debate, see Monell, 436 U.S. at 665, became what is now section 1983 . As originally proposed, the Sherman amendment would have held the individual citizens of each county, city, or parish liable for any constitutional violations that took place within the borders of that political subdivision. The amendment passed in the Senate by a vote of 39 to 25 but was rejected by the House. See Monroe v. Pape, 365 U.S. at 188-90 (citing Cong. GloBe, 42d Cong., 1st Sess. 663, 704-05, 725, 749, 800-01 (1871)).

The amendment was therefore referred to a conference committee. The committee's first proposal, which was at the center of most of the Sherman amendment debates, was again passed by the Senate but rejected by the House. It was more limited than the original version: it placed liability for damages directly on the municipality, rather than on the individual citizens, but only to the extent that the plaintiff's claim could not be satisfied by the individual responsible. Monell, 436 U.S. at 666-67 (citing Cong. Globe, 42d Cong., 1st Sess. 749, 755 (1871)).

The second conference substitute, which eliminated any reference to liability on the part of either innocent citizens or the municipality, was enacted as section six of the 1871 Act and is now codified as 42 U.S.C. $\S 1986$ (1976). Monell, 436 U.S. at 668-69 (citing Cong. GLoBE, 42d Cong., 1st Sess. 804 (1871)).

" Civil Rights Act of 1871 , ch. 22, 17 Stat. 13 (current version at 42 U.S.C. $\S \S 1983,1985$, 1986 (1976)).

${ }^{35}$ See, e.g., Turpin v. Mailet, 579 F.2d 152, 161 (2d Cir.) (en banc) ("it is difficult to draw any reasoned conclusion regarding Congress's attitude toward municipal liability for the constitutional torts of public employees from the fate of the Sherman amendment") (footnote omitted), vacated and remanded sub nom. City of West Haven v. Turpin, 439 U.S. 974 
The Sherman amendment was, like section 1983, aimed at controlling the systematic abuse of rights in the post-Civil War South by the Ku Klux Klan and similar groups..$^{36}$ Although both provisions were drafted upon the belief that constitutional violations were being tolerated by local governments and private citizens alike, ${ }^{37}$ their solutions were radically different. Section 1983 imposes liability on those responsible for the constitutional deprivation; the Sherman amendment, on the other hand, would have made municipalities strictly liable for all constitutional violations-whether committed by employees, citizens, or outsiders-that took place within their boundaries. ${ }^{38} \mathrm{By}$ imposing a form of collective liability, the amendment's supporters hoped to enlist the entire population in an effort to keep the peace. ${ }^{39}$ At the same time, the amendment would have insured compensation for all victims of constitutional violations.

Based on Congress's rejection of the Sherman amendment, the Monell Court made two closely related points to demonstrate that

(1978) (for reconsideration in light of Monell); Developments in the Law-Section 1983 and Federalism, 90 Harv. L. REv. 1133, 1191-92 (1977) [hereinafter cited as Developments]; Comment, Toward State and Municipal Liability in Damages for Denial of Racial Protection, 57 Caurf. L. Rev. 1142 (1969); Note, Damage Remedies Against Municipalities for Constitutional Violations, 89 HaRv. L. Rev. 922, 945-48 (1976).

36 The Act of 1871 is, indeed, known as the Ku Klux Klan Act. See.The Supreme Court, 1977 Term, supra note 6, at 311 n.2. Sections two, three, and four of the Act, defining certain federal crimes and providing for presidential mobilization of the militia and suspension of habeas corpus, were "aimed primarily at the Ku Klux Klan." Monell, 436 U.S. at 665 n.11. The first section of the Act-now section 1983- did, however, give a remedy to whites as well as blacks and therefore "went beyond the mischief to which the remaining sections of the 1871 Act were addressed." Id. at 683.

${ }^{37}$ Congressmen were apparently outraged both by repeated Klan excesses and by state inaction in the face of organized private violence. See Monroe v. Pape, 365 U.S. 167, 175-76 (1961); S. Rep. No. 1, 42d Cong., 1st Sess. (1871) (describing the violence for which the Klan was responsible); CoNG. Globe, 42d Cong., 1st Sess. 153-57 (1871) (remarks of Sen. Sherman) (concern over Klan violence); id. at 394 (remarks of Rep. Rainey) (courts refuse to uphold rights impartially); Developments, supra note 35, at 1153-56.

${ }^{38}$ The sponsors of the amendment apparently intended liability to attach only when the municipality was in some sense at fault. There is no such requirement in the language of the amendment, however, and many Congressmen believed it to be more broadly applicable. See Monell, 436 U.S. at 692 n.57 (citing CoNG. GLOBE, 42d Cong., 1st Sess. $751-52$ (1871) (remarks of Rep. Shellabarger); id. at 756 (remarks of Sen. Edmunds); id. at 761 (remarks of Sen. Sherman); id. at 771 (remarks of Sen. Thurman); id. at 788 (remarks of Rep. Kerr); id. at 791 (remarks of Rep. Willard)).

31 "Let the people of property in the southern States understand that if they will not make the hue and cry and take the necessary steps to put down lawless violence in those States their property will be holden responsible, and the effect will be most wholesome." Cong. Globe, 42d Cong., 1st Sess. 761 (1871) (remarks of Sen. Sherman). Accord, id. at 76061 (remarks of Sen. Sherman); id. at 794 (remarks of Rep. Kelley); id. at 751-52 (remarks of Rep. Shellabarger); id. at 757 (remarks of Sen. Edmunds). 
respondeat superior was inconsistent with congressional intent. First, the Court suggested that similar policies-deterrence and insurance-lie behind both respondeat superior and the Sherman amendment, so that allowing respondeat superior liability would give rise to the same constitutional objections that were raised by the opponents of the amendment..$^{40}$ Second, the Court reasoned that "Congress' rejection of the only form of vicarious liability presented to it"41 demonstrated congressional opposition to respondeat superior. Neither of these points is valid, however, for both involve a historically unjustified and internally inconsistent reading of congressional motives.

1. Similar Constitutional Objections. The Court's conclusion that respondeat superior would have engendered the same constitutional objections as the Sherman amendment seems to be incorrect for two reasons. First, contrary to the Court's analysis, the underlying policies sought to be effectuated by the two schemes of liability are significantly different. One goal of respondeat superior, that of forcing the municipality to deter its employees from official wrongdoing, is hardly identical with that of securing " 'a more perfect police regulation' "'42 against the unconstitutional acts of citizens and outsiders, the aim of the Sherman amendment. And requiring the municipality to self-insure against the wrongs of the agents it employs and controls for its benefit bears little relation indeed to the "mutual insurance" "43 against all wrongdoing proposed in the Sherman amendment.

Second, the congressional debates concerning the Sherman amendment indicate that the constitutional concerns of most legis-

so 436 U.S. at $693-94$.

"Id. at 692 n.57.

12 Id. at 694 (quoting CoNG. GLOBE, 42d Cong., 1st Sess. 777 (1871) (remarks of Sen. Frelinghuysen)). While the Monell Court equates this with the idea of cost-effective deterrence underlying respondeat superior liability, Senator Frelinghuysen's remark was apparently offered in a somewhat different context: he was referring to the new, affirmative obligation to provide police protection that the Sherman amendment imposed on municipalities. There is, of course, a difference between requiring a municipality to minimize harm caused by an existing police force acting within the scope of its employment, and requiring it to create a police force to prevent harm caused by outsiders. On the constitutional ramifications of this distinction, see text and notes at notes 49-50 infra.

${ }^{43}$ Monell, 436 U.S. at 694 (quoting Cong. GLOBE, 42d Cong., 1st Sess. 792 (1871) (remarks of Rep. Butler)). While Monell interprets Representative Butler's remarks as referring to selfinsurance, they actually refer to the universal insurance against all wrongdoing required by the amendment. The meaning is made clear by the remarks of Representative Kelley: " $[B] y$ making the whole body of citizens insurers for the victims you will have a safeguard which no police arrangement can make, one more effective than any other . . . " CoNG. GLOBE, 42d Cong., 1st Sess. 794 (1871) (Remarks of Rep. Kelley). 
lators had no relevance to the limited policies served by respondeat superior liability. Perhaps the major objection to the amendment raised in the House of Representatives, drawing upon the theory of dual sovereignty enunciated in cases like Collector $v$. Day, ${ }^{H}$ was that the federal government could not force political subdivisions of the states to keep the peace or create police forces..$^{45}$ Such an obligation would have been indirectly created by the Sherman amendment damages remedy. Thus Representative Blair said of the amendment: "If [Congress] can say that [a municipality] shall be liable for damages occurring from a riot . . . where [will] its power ... stop and what obligations . . . might [it] not lay upon a municipality ...."4s Sherman amendment opponents in the Senate used the same theory to support a different argument. They focused not on the establishment of the obligation but on the means of enforcement: creation of an automatic lien on all the municipality's money and property. ${ }^{47}$ This would, under the principle of Collector v. Day, violate the Constitution's dual-sovereignty principle by threatening the integrity of municipal operations. ${ }^{48}$

These objections, however, have no implications for a scheme that would hold municipalities liable only for the unconstitutional actions of their employees. ${ }^{49}$ Respondeat superior liability would not

" 78 U.S. (11 Wall.) 113 (1870). In Day, the Court held that the federal government could not tax the salary of a state judicial officer because "the state is as sovereign and independent as the general government." Id. at 127.

is See Monell, 436 U.S. at 673-75. Since municipalities were seen as agents of state control, imposing affirmative duties on them would impede the states from pursuing their legitimate activities.

"Cong. Globe, 42d Cong., 1st Sess. 795 (1871), cited in Monell, 436 U.S. at 675. See also Monell, 436 U.S. at 673-74 n.30 (listing those Sherman amendment opponents who agreed with Representative Blair's view).

${ }^{17}$ See 436 U.S. at 673 n.30. See also id. at 706 (Powell, J., concurring).

13 Creating an automatic lien on all of the municipality's property would discourage outsiders from trading with it, adversely affecting municipal operations. See, e.g., ConG. GLOBE, 42d Cong., 1st Sess. 762 (1871) (remarks of Sen. Stevenson). In contrast, no automatic lien is imposed on all municipal property in suits under section 1983. It is true that some Sherman amendment opponents argued that drawing any damages from municipal resources would make it impossible for the government to function effectively, and would give the federal government the power to destroy an essential state instrumentality. See, e.g., id. But the willingness of the Monell Court to hold that a municipality constitutes a person under section 1983 suggests that the Court did not believe this objection to be widely held by Sherman amendment opponents.

"The Monell Court concluded that even under the theory of dual sovereignty there is "no limit on the power of federal courts to enforce the Constitution against municipalities that violated it." 436 U.S. at 680 . Thus, unless the Reconstruction legislators interpreted the theory differently, they would have viewed a scheme of respondeat superior liability as violative of dual sovereignty only if they believed that municipalities were in no sense responsible for the acts of their employees-an unlikely proposition. 
force municipalities to create police forces or keep the peace, since it imposes liability on the city only for the acts of those who are already employees. And it cannot force the city to insure against wrongs committed by private citizens, since respondeat superior liability can attach only when the principal has control over-and is thus responsible for-the agent's actions..$^{50}$ As for the integrity of municipal corporations, the judgment imposed on a municipality under section 1983 does not institute a lien on all of the municipal' ity's property-and, at any rate, a section 1983 judgment can now be entered under the rationale of Monell itself.

The other arguments raised in debate against the Sherman amendment similarly fail to establish that Congress intended to preclude section 1983 respondeat superior liability. Some opponents of the amendment, for example, suggested that it was unconstitutional because it would make municipalities liable in federal court when there was no state action involved, ${ }^{51}$ or when no constitutionally protected interest had been violated.52 Still others were convinced that the proposal would force citizens to pay for violations over which neither they nor their elected officials had any control. ${ }^{53}$ But unlike the Sherman amendment, section 1983 has a state action requirement. And unlike the Sherman amendment, respondeat superior applies only when the municipality and its officers are in a position to control directly the acts of municipal employees.

2. Rejection of Vicarious Liability. The Court's second rationale-that Congress rejected a scheme of private vicarious liability and thus rejected vicarious liability generally $y^{54}$-is too broad, for all municipal action, even that of the "official" kind, is by definition

so See Restatement, supra note $5, \S 220(1)$. It is only when such control exists that the policies behind respondeat superior are served: the employer pays for anticipated harms caused by those working for his benefit. See generally W. Prosser, supra note 5, §§ 69-70.

is See Cong. Globe, 42d Cong., 1st Sess. 788-89 (1871) (remarks of Rep. Kerr); id. at 794 (remarks of Rep. Poland); id. at 822 (remarks of Sen. Thurman).

${ }_{52}$ See id. at 788-89 (remarks of Rep. Kerr); id. at 822 (remarks of Sen. Thurman).

s See id. at 762 (remarks of Sen. Stevenson); id. at 771 (remarks of Sen. Thurman); id. at 777 (remarks of Sen. Frelinghuysen); id. at 788 (remarks of Rep. Kerr); id. at 791 (remarks of Rep. Willard); id. at 798-99 (remarks of Rep. Farnsworth).

54 See text and note at note 41 supra. The Court also drew support for its analysis from the fact that Congress ultimately passed a substitute for the Sherman amendment-now 42 U.S.C. section 1986, see note 33 supra-which imposes liability on those who were directly at fault. 436 U.S. at 693 n.57. But that Congress adopted what is now section 1986 says nothing about what was seen as objectionable in the Sherman amendment, and therefore "its enactment in lieu of the Sherman amendment does not create an inference that Congress had a policy-based objection to imposition of vicarious liability on municipalities." Baskin v. Parker, 602 F.2d 1205, 1213 (5th Cir. 1979) (Rubin, J., concurring in part and dissenting in part). 
vicarious. ${ }^{55}$ Accepting the Court's argument would therefore support a rejection of municipal liability altogether, but that of course is contrary to the holding of Monell. Moreover, the fact that Congress rejected an extreme form of vicarious liability-albeit the only explicit form of vicarious liability presented to it-provides little support for the Monell Court's rejection of respondeat superior; it is no more persuasive than the argument that Congress's rejection of the Sherman amendment's municipal-liability scheme justified the illconsidered municipal-immunity rule of Monroe $v$. Pape. ${ }^{56}$

Justice Brennan apparently recognized the tenuousness of the link between the Sherman amendment and section 1983, conceding that "[s]trictly speaking . . . the fact that Congress refused to impose vicarious liability for the wrongs of a few private citizens does not conclusively establish that it would similarly have refused to impose vicarious liability for the torts of a municipality's employees." 57 And given the essential differences between the Sherman amendment and section 1983 respondeat superior liability-as well as the fact that the constitutional problems perceived in the first are not present in the second-it is difficult to discern any basis for the inference the Court drew from Congress's rejection of the amendment.

\section{The Prior Construction of Section 1983}

To strengthen its conclusion that section 1983 liability requires a more direct causal link than is afforded by respondeat superior, the Monell Court cited Rizzo v. Goode, ${ }^{58}$ an earlier Supreme Court opinion construing the statute. The Monell Court, however, seems to have read more into Rizzo than is actually there. At the same

ss See note 29 supra. Nineteenth-century courts were aware of the distinction between private vicarious liability and respondeat superior. See, e.g., Prather v. City of Lexington, $52 \mathrm{Ky}$. (13 B. Monroe) 559, 560, 561 (1852) (municipality liable for actions of employees done "in pursuance of a general authority to act for the corporation," but there is "no principle of law, that subjects a municipal corporation to a responsibility for the safety of the property within its territorial limits").

56 The Court in Monroe v. Pape, interpreting Representative Poland's statement that "Congress had no constitutional power to impose any obligation upon county und town organizations," Cong. Glose, 42d Cong., 1st Sess. 804 (1871) (remarks of Rep. Poland), concluded that in rejecting the Sherman amendment Congress believed it had no constitutional power to impose civil liability on municipalities. 365 U.S. at 190-91. The Monroe Court, like the Monell Court, thus read too much into the rejection of the Sherman amendment. The Monell Court concluded from a more extensive canvass of the Sherman amendment debates, however, that "obligation" referred to "affirmative duty" rather than "civil liability." See Monell, 436 U.S. at 665, 678-80.

57436 U.S. at 692 n.57.

ss 423 U.S. 362 (1976). 
time, the Court disregarded several independent lines of cases strongly indicating that respondeat superior is not inconsistent with section 1983.

1. Rizzo v. Goode. In Rizzo, the Court heard the appeal of two section 1983 actions brought against several high-level Philadelphia officials. ${ }^{59}$ The plaintiffs alleged a "pervasive pattern of illegal and unconstitutional mistreatment by police officers." courts granted an injunction against the officers; ${ }^{61}$ the Supreme Court reversed..$^{62}$ Rizzo does not, however, support the proposition that the prior construction of section 1983 is inconsistent with respondeat superior. ${ }^{.3}$

The suit in Rizzo was aimed not at the city of Philadelphia but at high-level city officials. And while obtaining equitable relief against a city officer in many ways has the same effect as obtaining such relief against the city itself, the Court treated Rizzo as a suit against individuals. The issue was framed as whether the named defendants had a personal duty to eliminate police misconduct, and were therefore personally at fault. ${ }^{64}$ Thus, the Court held that since "none of the petitioners had deprived the respondent classes of any rights secured under the Constitution ... this case presented no occasion for the District Court to grant equitable relief against petitioners." "65

The Rizzo Court's refusal to impose section 1983 liability on supervisors, however, is not inconsistent with respondeat superior liability for municipalities. Under the doctrine of respondeat superior, supervisory officials are never personally liable for the acts of subordinates; ${ }^{86}$ the doctrine applies only to employers.

39 The mayor, city managing director, police commissioner, and two subordinate police supervisors were named as defendants. Id. at 364 n.1.

${ }^{60} \mathrm{Id}$. at 366.

31 Council of Organizations on Philadelphia Police Accountability \& Responsibility v. Rizzo, 357 F. Supp. 1289, 1321 (E.D. Pa. 1973), aff'd sub nom. Goode v. Rizzo, 506 F.2d 542 (3d Cir. 1974), rev'd, 423 U.S. 362 (1976).

62423 U.S. at 381.

63 The Rizzo Court did stress the need for a causal link. Id. at 370-71 ("The plain words of the statute impose liability . . . only for conduct which 'subjects, or causes to be subjected' the complainant to a deprivation of a right secured by the Constitution and laws."). Section 1983's causation requirement is not, however, inconsistent with the doctrine of respondeat superior. See text and note at note 31 supra.

st 423 U.S. at $375-77$.

55 Id. at 377 (emphasis added). Rizzo rested on two additional alternative holdings: (1) the lack of a case or controversy, id. at 371-73, and (2) the federalism concerns raised by the wide-ranging character of the requested equitable relief, id. at 377-80. For a discussion of the federalism issues raised by respondeat superior, see text and notes at notes 114-157 infra.

${ }_{B B}^{B B}$ Respondeat superior liability attaches only when the servant acts for the benefit of the master. See, e.g., 1 E. JAGGARD, HAND-BOOK OF THE LAW OF TORTS $\$ 83(b)$, at 252-53 (1895); 
2. The Contrary Lines of Cases. The Monell Court, apart from placing unfounded reliance on Rizzo, ignored several lines of cases imposing vicarious liability in section 1983 actions. First, private corporations acting under color of state law had been held liable under the statute on the basis of respondeat superior. ${ }^{67}$ Second, the District of Columbia Circuit had concluded that respondeat superior is appropriate in section 1983 suits brought against the

W. Prosser, supra note $5, \S 70$, at $4 \widehat{6} 1-63$. Since a supervisor does not personally benefit from the acts of his subordinate, respondeat superior is inapplicable. See, e.g., Jennings v. Davis, 476 F.2d 1271, 1275 (8th Cir. 1973) (section 1983 suit against supervisor) ("[T]he 'master' . . . is and can only be the municipality employing the appellees. It is the city who set the enterprise in motion, who 'profits' from appellees' labor and who, if held liable in such instances, can by its powers of taxation spread the resulting expenditures amongst the community at large.") (footnote omitted); Carter v. Carlson, 447 F.2d 358, 370 n.39 (D.C. Cir. 1971) ("A superior officer is not subject to vicarious liability for the torts of his subordinate . . . because they are both servants of the same employer") (citation omitted), rev'd in part on other grounds sub nom. District of Columbia v. Carter, 409 U.S. 418 (1973); Milburn v. Girard, 429 F. Supp. 865, 867 (E.D. Pa. 1977); Wilkerson v. Mock, 403 F. Supp. 971, 973-74 (E.D. Pa. 1975); People v. Standard Accident Ins. Co., 42 Cal. App. 2d 409, 108 P.2d 923, 925 (1941).

" E.g., Croy v. Skinner, 410 F. Supp. 177 (N.D. Ga. 1976); Hill v. Toll, 320 F. Supp. 185 (E.D. Pa. 1970). Private corporations may be defendants in section 1983 suits because corporations and their employees can, under certain circumstances, operate under color of state law. See Hill v. Toll, 320 F. Supp. 185, 186-87 (E.D. Pa. 1970) (surety company); DeCarlo v. Joseph Horne \& Co., 251 F. Supp. 935 (W.D. Pa. 1966) (detective company clothed with statutory authority). But see Jobson v. Henne, 355 F.2d 129, 133 (2d Cir. 1966) ("test [under color of law] can rarely be satisfied in the case of anyone other than a state official"); Warren v. Cummings, 303 F. Supp. 803 (D. Colo. 1969); Weyandt v. Mason's Stores, Inc., 279 F. Supp. 283 (W.D. Pa. 1968).

In Hill v. Toll, 320 F. Supp. 185 (E.D. Pa. 1970), a Pennsylvania district court denied a motion to dismiss a section 1983 complaint against the defendant surety company after holding that the doctrine of respondeat superior was "impliedly a part of the Civil Rights Act." Id. at 189. The court reasoned that although section 1983 was predicated on notions of blameworthiness-at least as interpreted by the Supreme Court in Monroe-respondeat superior was not precluded; both doctrines, the court observed, "co-exist harmoniously at common law." Id. at 188 . The court concluded that respondeat superior should be applied in section 1983 actions so as to furnish "a 'deep pocket' from which a claimant can collect." Id.

Several pre-Monell decisions did, however, reject the use of respondeat superior against private employers in section 1983 claims. E.g., Draeger v. Grand Central, Inc., 504 F.2d 142 (10th Cir. 1974); Weiss v. J.C. Penny Co., 414 F. Supp. 52 (N.D. Ill. 1976). Draeger ruled out respondeat superior after improperly relying on a line of cases, Jennings v. Davis, $476 \mathrm{~F} .2 \mathrm{~d}$ 1271 (8th Cir. 1973); Adams v. Pate, 445 F.2d 105 (7th Cir. 1971); Ashenhurst v. Carey, 355 F. Supp. 1111 (N.D. Ill. 1973); Barnes v. Dorsey, 354 F. Supp. 179 (E.D. Mo. 1973); Boyden v. Troken, 352 F. Supp. 722 (N.D. Ill. 1973), that involved claims of vicarious liability against superior officials for the acts of subordinates. 504 F.2d at 145 . These cases are not inconsistent with an application of respondeat superior to section 1983 claims against municipalities. See text and note at note 66 supra. Nor did Weiss v. J.C. Penney Co., 414 F. Supp. 52 (N.D. Ill. 1976), provide a principled basis for rejecting respondeat superior in the nonmunicipality context. It relied on both the unsupporting precedent of Adams v. Pate, 445 F.2d 105 (7th Cir. 1971), one of the superior-official cases cited in Draeger, and Draeger. 414 F. Supp. at 53. 
District. ${ }^{68}$ Third, many courts, using state law, had imposed vicarious liability under the authority of section $1988^{69}$ in actions brought under section $1983 .{ }^{70}$ Section 1988 permits state law to be used in civil rights suits-but only when that law is consistent with the language and purposes of the civil rights statute. These courts must therefore have implicitly considered vicarious liability to be consistent with the words of section 1983. In addition, respondeat superior liability had been imposed by the Third Circuit ${ }^{71}$ in an action brought under the Civil Rights Act of $1870^{72}$ - a statute similarly silent as to vicarious liability. ${ }^{73}$

5. Carter v. Carlson, 447 F.2d 358, 366-67 (D.C. Cir. 1971), rev'd in part on other grounds sub nom. District of Columbia v. Carter, 409 U.S. 418 (1973). On appeal, however, the Supreme Court held that section 1983 does not apply in the District. Id. at 429-32. The Supreme Court consequently did not consider the propriety of section 1983 respondeat superior liability.

In the lower court opinion, then-Chief Judge Bazelon concluded that Monroe did not preclude the section 1983 claims against the District; the court then held the District liable under the statute on the basis of respondeat superior. In finding the doctrine applicable, Chief Judge Bazelon properly noted that those courts that have "suggested that there can be no vicarious liability under $\S 1983$," have really based their decisions on the notion that "a superior officer is not subject to vicarious liability for the torts of his subordinate . . . because they are both servants of the same employer." Id. at 370 n.39 (citations omitted).

69 Civil Rights Act of 1866 , ch. $31, \S 3,14$ Stat. 27 (current version at 42 U.S.C. $\S 1988$ (1976)) (state law applicable to actions brought under Civil Rights statutes when consistent).

${ }_{70}$ E.g., Scott v. Vandiver, 476 F.2d 238, 242 (4th Cir. 1973); Hesselgesser v. Reilly, 440 F.2d 901, 903 (9th Cir. 1971); Lewis v. Brautigam, 227 F.2d 124, 128 (5th Cir. 1955).

" Mahone v. Waddle, 564 F.2d 1018 (3d Cir. 1977), cert. denied, 438 U.S. 904 (1978). In Mahone, the city of Pittsburgh was held liable under 42 U.S.C. section 1981 for the racially motivated misconduct of its employees. The court pointed to differences between sections 1981 and 1983 to avoid the Monroe v. Pape municipal-immunity rule. But the court's analysis is nonetheless relevant to section 1983, because both provisions were passed while the "dual sovereignty" theory of federalism was in vogue. See text and notes at notes 44-48 supra. Although basing the city's section 1981 liability on respondeat superior, see 564 F.2d at 1021, the court never discussed the question whether section 1981 demanded application of such a doctrine.

${ }^{72}$ Act of May 31,1870 , ch. 114, $\S 16,16$ Stat. 144 (current version at 42 U.S.C. $\S 1981$ (1976)).

${ }^{73}$ In at least one line of cases-involving suits brought against municipalities directly under the fourteenth amendment--many courts have rejected municipal respondeat superior. Such suits are based on Bivens v. Six Unknown Named Agents of Federal Bureau of Narcotics, 403 U.S. 388 (1971), which held that in the absence of special factors counselling inesitation, a remedy for official misconduct can be fashioned directly from the Constitution Id. at 396. Although the Supreme Court before Monell neither approved nor disapproved the use of such actions against municipalities, in City of Kenosha v. Bruno, 412 U.S. 507, 514 (1973), it remanded such a claim to see if $\$ 10,000$ - the minimum amount for federal jurisdiction under 28 U.S.C. section 1331-was in controversy. See Note, Damage Remedies Against Municipalities for Constitutional Violations, supra note 35, at 929-30. Fourteenth amendment actions against municipalities have since been accepted in most circuits. See Davis v. Passman, 571 F.2d 793, 807 n.6 (5th Cir. 1978) (Goldberg, J., dissenting) (reviewing the decisions of each circuit), rev'd, 99 S. Ct. 2264 (1979); Comment, Municipal Liability for Constitutional Violations: Can You Fight City Hall?, 16 DuQ. L. Rev. 373 (1978). 
Obviously, none of these lower court cases compel the Supreme Court to adopt section 1983 municipal respondeat superior. But these decisions do constitute a substantial body of authority in lavor of that position-a body of authority that was not addressed by the Monell Court. Indeed, Monell, by finding all forms of vicarious liability inconsistent with section 1983, seems to require overturning each of these lines of cases-a result apparently not anticipated by the Court. ${ }^{74}$

At the same time, the Court failed to take into account its own decisions construing section 1983 against the background of tort law and reading into the statute a variety of common-law tort principles. ${ }^{75}$ To be faithful to those cases, then, it is necessary to conduct a fuller exploration of the statutory background and purposes.

It is true that most courts that have allowed municipal liability under Bivens have nevertheless rejected respondeat superior. They have done so, however, for reasons relating to the peculiar nature of the nonstatutory claim; their objections have no relevance to section 1983 actions. In Kostka v. Hogg, 560 F.2d 37 (1st Cir. 1977), for example, Chief Judge Coffin declined to infer a respondeat superior action from the Constitution because such a course would require too great an exercise of judicial initiative, given the congressional hostility to municipal liability evidenced in Monroe v. Pape. $560 \mathrm{~F} .2 \mathrm{~d}$ at 43-44. The court left open what it would do if it were "faced with a case in which the municipality had ordered the constitutional violation," id. at 45 .

In Turpin v. Mailet, 579 F.2d 152 (2d Cir.) (en banc), vacated and remanded sub nom. City of West Haven v. Turpin, 439 U.S. 974 (1978) (for reconsideration in light of Monell), the Second Circuit reached a similar conclusion through a somewhat different analysis. Turpin held respondeat superior inappropriate in a direct constitutional action against a municipality because it considered Bivens to require a culpable defendant. Id. at 166 . The court also seemed to interpret Bivens as requiring the absence of any statutory cause of action, $i d$. at 166; since the plaintiff could have sued the individual wrongdoer under section 1983, a respondeat superior Bivens-type action was inappropriate. Other courts denying respondeat superior liability in fourteenth amendment actions have done so for similar reasons. See, e.g., Jamison v. McCurrie, 565 F.2d 483, 485 (7th Cir. 1977); McDonald v. Illinois, 557 F.2d 596, 604 (7th Cir.), cert. denied, 434 U.S. 966 (1977); Dunlap v. City of Chicago, 435 F. Supp. 1295, 1301-03 (N.D. Ill. 1977). Several courts have, however, applied respondeat superior in Bivens-type actions against municipalities. E.g., Santiago v. City of Philadelphia, 435 F. Supp. 136, 148-49 (E.D. Pa. 1977); Collum v. Yurkovich, 409 F. Supp. 557, 558-59 (N.D. Ill. 1975); Williams v. Brown, 398 F. Supp. 155, 160-61 (N.D. Ill. 1975).

While it has been suggested that the fourteenth amendment action will, even after Monell, provide a vehicle for bringing suits against municipalities, see, e.g., 47 U. CIN. L. REv. 670, 676-77 (1979), courts apparently consider themselves bound by the congressional antipathy to respondeat superior perceived in Monell. See, e.g., Kedra v. City of Philadelphia, 454 F. Supp. 652, 678 (E.D. Pa. 1978).

7 The first case to consider the impact of Monell on any of these lines of cases seems to have been Baskin v. Parker, 602 F.2d 1205 (5th Cir. 1979) (per curiam). There, the Fifth Circuit found in a section 1983 action that a sheriff cannot be held vicariously liable under state law applied through section 1988, 42 U.S.C. \& 1988 (1976), because "[a]llowing Louisiana's vicarious liability rules to govern this case would be directly contrary to Monell's construction of $\S 1983$, and thus to the requirements of $\S 1988 . "$ Id. at 1208.

${ }^{73}$ See text and notes at notes 21-25 supra. 


\section{The Case for Respondeat Superior}

The language of section 1983 does not itself define the contours of municipal liability. A strong argument can be made, however, that given Congress's purposes in enacting section 1983 and the background of municipal tort liability in 1871 , Congress intended to impose respondeat superior liability on municipalities.

\section{A. The Reach of Section 1983}

The Reconstruction Congress viewed section 1983 as a remedial statute that should be liberally construed; ${ }^{76}$ the Supreme Court has given the Civil Rights Acts "[a] sweep as broad as [their] language.' '77 Thus, if respondeat superior liability advances the congressional purposes underlying section 1983-deterrence of and compensation for constitutional violations committed by state and local officials ${ }^{8}$-municipal liability for employee torts arguably falls within the ambit of the statute..$^{79}$

${ }^{7}$ See, e.g., CoNg. GLoBe, 42d Cong., 1st Sess. app. 68 (1871) (remarks of Rep. Shellabarger) ("All statutes and constitutional provisions authorizing such statutes are liberally and beneficently construed."); id. at 800 (remarks of Rep. Perry) ("we have asserted as fully as we can assert the mischief intended to be remedied . . . . We have also asserted as fully as we can assert the constitutional right of Congress to legislate."); id. at app. 81 (remarks of Rep. Bingham) (section 1983 is designed to secure "the enforcement . . . of the Constitution on behalf of every individual citizen of the Republic . . . to the extent of the rights guaranteed to him by the Constitution"); cf. id. at app. 216-17 (remarks of Sen. Thurman) (criticizing the statute's broad language because "[t]here is no limitation whatsoever upon the terms that are employed, and they are as comprehensive as can be used").

${ }^{77}$ Griffin v. Breckenridge, 403 U.S. 88, 97 (1971) (quoting United States v. Price, 383 U.S. 787, 801 (1966)).

${ }^{7 k}$ See, e.g., Robertson v. Wegmann, 436 U.S. 584, $590-91$ (1978) ("The policies underlying $\S 1983$ include compensation of persons injured by deprivation of federal rights and prevention of abuses of power by those acting under color of state law."). See generally Nahmod, supra note 24, at 9.11. The effectiveness of section 1983 in meeting these goals has, however, been seriously brought into question by a recent study of section 1983 litigation against police. See Project, Suing the Police In Federal Court, 88 Yaus L.J. 781 (1979).

79 The use of respondeat superior in the municipal context as a means of encouraging compensation and discouraging wrongdoing has been widely advocated by both courts and commentators. See, e.g., Dellums v. Powell, 566 F.2d 216, 222-25 (D.C. Cir. 1977); Carter v. Carlson, 447 F.2d 358, 365-67 (D.C. Cir. 1971), rev'd in part on other grounds sut nom. District of Columbia v. Carter, 409 U.S. 418 (1973); Santiago v. City of Philadelphia, 435 F. Supp. 136, 148-49 (E.D. Pa. 1977); Sanabria v. Village of Monticello, 424 F. Supp. 402, $410-$ 11 (S.D.N.Y. 1976); Williams v. Brown, 398 F. Supp. 155 (N.D. Ill. 1975); Hundt, Suing Municipalities Directly Under the Fourteenth Amendment, 70 Nw. U.L. Rev. 770, 779-82 (1975); Kates \& Kouba, Liability of Public Entities Under Section 1983 of the Civil Rights Act, 45 S. CaL. L. Rev. 131 (1972); Newman, Suing the Lawbreakers: Proposals to Strengthen the Section 1983 Damage Remedy for Law Enforcers' Misconduct, 87 YALE L.J. 447, 455-58 (1978); Note, A Federal Cause of Action Against a Municipality for Fourth Amendment Violations by Its Agents, 42 GEo. WAsH. L. REv. 850 (1974); Note, Accountability for Govern- 
1. Compensation. Section 1983's goal of compensating individuals for violations of their constitutional rights ${ }^{80}$ will unquestionably be frustrated by the Court's refusal to impose respondeat superior liability on municipalities. First, as an evidentiary matter, it is often impossible for the plaintiff to identify the individual responsible for the abuse, ${ }^{81}$ although the victim can demonstrate that the wrongdoer was a municipal employee. Further, by requiring the plaintiff to show "municipal involvement" in order to satisfy Monell's requirements, a difficult legal barrier is established. ${ }^{.2} \mathrm{Fi}$ nally, on a practical level, the employee-defendant is likely to be either judgment proof ${ }^{83}$ or, as a municipal agent, viewed sympathetically by the jury. ${ }^{84}$

ment Misconduct: Limiting Qualified Immunity and the Good Faith Defense, 49 TEMP. L.Q. 938, 971-73 (1976). See also Comment, supra note 35.

*o It is settled law that violations of constitutional rights may be compensable harms. See, e.g., Scheuer v. Rhodes, 416 U.S. 232, 238 (1974); Bivens v. Six Unknown Named Agents of Federal Bureau of Narcotics, 403 U.S. 388, 397 (1971); Baskin v. Parker, 588 F.2d 965, 970 (5th Cir. 1979). See generally Nahmod, supra note 24 . The Court has recently held, however, that damages may be awarded only for actual harm. Carey v. Piphus, 435 U.S. 247, 264 (1978)

ะI See, e.g., Howell v. Cataldi, 464 F.2d 272, 282-84 (3d Cir. 1972).

82 One district court required the plaintiff to demonstrate in his pleadings either the details of municipal involvement in the violation or other instances of misconduct by a municipal employee. The court hoped to avoid having municipalities named as defendants in every civil rights suit, both to protect local governments from undue fiscal burdens and to avoid unnecessarily long trials. Smith v. Ambroglio, 456 F. Supp. 1130 (D. Conn. 1978).

"s See S. REP. No. 588, 93d Cong., 1st Sess. 3 (1973) ("Federal agents are usually judgment proof"); S. REP. No. 469, 93d Cong., 1st Sess. 36 (1973) (remarks of Sen. Percy) (“causes of action against officials as individuals will, on occasion, be virtually worthless since government employees may be so lacking in funds as to be judgment proof'); Kates \& Kouba, supra note 79, at 136-37; Note, Vicarious Liability Under Section 1983, 6 IND. L. REv. 509, 515 (1973). In addition, most municipal employees lack insurance against damage judgments. See F. HARPER \& F. James, The LAW OF TORTS § 26.1 (1956).

Many jurisdictions do indemnify public officers for job-related liabilities they incur. Such indemnification, however, does not seem to further significantly the compensatory and deterrence goals of section 1983:

If the officer is judgment proof, neither compensation nor substantial deterrence is likely to result, even when the plaintiff wins. Ironically, those jurisdictions that provide indemnification for the police officer do little to make the lawsuit more effective. Actually, where indemnification is available, the present system of suing only the individual wrongdoer combines the worst of both worlds. The jurors, not informed of indemnification, think the officer will personally have to pay any damages awarded, so they tend to find for defendants and, when damages are awarded, to keep the amount at a modest level. Yet the defendant is not deterred from wrongdoing by the prospect of paying damages, for he knows that any damage award will be covered by municipal indemnification.

Newman, supra note 79, at 456-57.

st See Bivens v. Six Unknown Named Agents of Federal Bureau of Narcotics, 403 U.S. 388, 421-22 (1971) (Burger, C.J., dissenting); Project, supra note 78, at 800-02. But see Molina v. Richardson, 578 F.2d 846 (9th Cir.), cert. denied, 439 U.S. 1048 (1978) (concern over jury sympathies is only speculative). 
Under a scheme of respondeat superior liability, these impediments to effectuating section 1983's goal of compensation are removed. The legal and evidentiary burden carried by the plaintiff is reduced: while the victim must still establish that the violation is of constitutional magnitude, he need only show in addition that the individual wrongdoer was an employee of the municipality acting in the course of his employment. ${ }^{85}$ And by imposing liability on the municipality, respondeat superior ensures that damages will be paid by a defendant with "deep pockets." 86

2. Deterrence. The deterrence of constitutional violations committed by those acting "under color of" state law would also be aided by respondeat superior. The Court in Monroe v. Pape noted that section 1983 was designed to deter potential wrongdoers by providing victims with a federal forum for the enforcement of fourteenth amendment rights. ${ }^{87}$ Respondeat superior liability guarantees victims access to that forum even if the individual wrongdoer is unavailable. Moreover, since the municipality-the employer of the wrongdoer-must bear the costs of the violation, municipal officials are likely to take steps to deter city employees from committing constitutional torts. ${ }^{88}$ Such a scheme would thus encourage the establishment of more effective municipality-wide deterrence mechanisms than if liability were limited to a host of possibly unidentifiable or judgment-proof individual defendants. And the deterrent effect of personal liability would not be lost, since individual wrongdoers would remain potentially liable under section $1983 .{ }^{89}$

${ }^{85}$ See note 5 supra.

${ }^{86}$ See, e.g., Project, supra note 78, at 817. See also G. CALABRESI, The Costs of Accidents 21 (1970). The recent study of section 1983 litigation against police, Project, supra note 78, recommended that "in order to make section 1983 suits more effective . . . municipalities should be made strictly liable for the unconstitutional acts of their police officers." Id. at 816 . The study concluded that "adoption of a standard of strict liability will ensure that damages awarded to successful plaintiffs will be paid by 'deep pocket' defendants." Id. at 817 . What the study labels a scheme of strict liability seems to be one of respondeat superior. See id. at 816 ("It is unfair and impractical to demand that before a municipality is held liable, the plaintiff must show a causal link.").

87365 U.S. at 182-83. The Court has in several instances emphasized the importance of providing a federal forum for constitutional claims: hostile state courts might thwart the vindication of constitutional rights. See, e.g., Mitchum v. Foster, 407 U.S. 225, $238-43$ (1972); Chevigny, Section 1983 Jurisdiction: A Reply, 83 HaRv. L. Rev. 1352, 1356-60 (1970); Laycock, Federal Interference with State Prosecutions: The Need for Prospective Relief, 1977 Sup. CT. Rev. 193, 233-34; Neuborne, The Myth of Parity, 90 HaRv. L. REv. 1105 (1977).

s See Jaffe, Suits Against Government and Officers: Damage Actions, 77 HaRv. L. Rev. 209, 229-30 (1963); Kates \& Kouba, supra note 79, at 140-41. See generally R. Posner, Economic ANalysis of LAW 119-59 (2d ed. 1977); Note, supra note 35, at 923-24.

89 There is something to the argument that if the treasury pays, the deterrent effect of the judgment on the police officer is dulled. But perhaps the weight of the argument as 
3. The "Fairness" of Respondeat Superior. The argument can be made that it is unfair to impose liability on a municipality that in many instances has "committed" no wrong other than that of employing the individual wrongdoer. But the contention seems to misapprehend the nature of municipal vicarious liability: not only is the municipality acting through its agent when the violation is committed, ${ }^{90}$ it has clothed the employee with the governmental authority necessary for a constitutional abuse to take place.91 Thus, the constitutional violations committed by municipal employees acting within the scope of their employment are costs of municipal government that should properly be distributed among the local citizenry. ${ }^{92}$ Indeed, someone-the wrongdoer, his employer, or the victim-must absorb the cost of the injury. ${ }^{93}$ When the wrongdoer cannot be reached, it seems fair to shift the cost to the employer-in this case, the community at large-because the municipality is in the better position to prevent future constitutional violations. In sum, where the choice is between imposing the loss on the victim or imposing it on the municipality, the latter seems preferable.

\section{B. The Background of Municipal Tort Liability}

The legislative purpose has not been the only guide used by the courts in construing section 1983. Judicial interpretation of the statute has also traditionally been shaped by tort-law concepts. ${ }^{94}$ In

to deterrence is the other way. If recovery can be had only against the officer and he is judgment-proof, deterrence is at a minimum. If a judgment is collected against the state, the state may in outrageous cases have recourse against the officer either out of his funds or in the form of discipline. Furthermore, police tactics are often institutional and awards against the state may modify institutional practices.

Jaffe, supra note 88, at 229-30.

"See, e.g., text and note at note 29 supra.

"See Scheuer v. Rhodes, 416 U.S. 232, 243 (1974) (section 1983 protects citizens against the " "misuse of power . . . made possible only because the wrongdoer is clothed with the authority of state law" ") (quoting United States v. Classic, 313 U.S. 299, 326 (1941)); Carter v. Carlson, 447 F.2d 358, 366 (D.C. Cir. 1971) ("When a tort is made possible only through the abuse of power granted by the government, then the government should be held accountable for the abuse"), rev'd in part on other grounds sub nom. District of Columbia v. Carter, 409 U.S. 418 (1973); Culp v. Devlin, 437 F. Supp. 20, 24 (E.D. Pa. 1977) (respondeat superior "imposes liability on the entity which hired the police officer and gave him the opportunity to commit a constitutional violation").

12 It has been suggested that compensation for violations of rights that will unavoidably be perpetrated by municipal officials might be considered a "background cost of citizenship." Developments, supra note 35, at 1218. Accord, Note, supra note 35, at 957.

'3 "If municipalities are not held liable ... the social and economic burden of police misconduct is borne by the uncompensated victims. The cost does not disappear merely because recovery is not allowed." Project, supra note 78, at 817 n.199.

'See text and note at note 21 supra. 
Monell, however, the Court ignored the principles of municipal tort liability that formed the background for section 1983. But if Congress in enacting the statute intended to impose liability on municipalities, it seems likely that the contours of that liability were shaped by the law of the day. Perhaps the surest guide to congressional intent, then, is the basic shape of nineteenth-century tort law.

At the beginning of the nineteenth century, municipalities ${ }^{95}$ in most American jurisdictions were not absolutely immune from suit in tort, as is commonly believed $\dot{;}^{96}$ they were, rather, routinely held liable for torts committed by their employees. ${ }^{97}$ While the contours

${ }^{95}$ The discussion in text deals only with incorporated municipalities. Unincorporated governmental units-"quasi-corporations"-probably were considered immune in this country from the beginning, Barnett, The Foundations of the Distinction Between Public and Private Functions in Respect to the Common-Law Tort Liability of Municipal Corporations, 16 OR. L. REv. 250, 264 (1937), unless made liable by statute, see, e.g., Mower v. Inhabitants of Leicester, 9 Mass. 237, 239-40 (1812); Riddle v. Proprietors of the Locks \& Canals on Merrimack River, 7 Mass. 169 (1810). Much of the uncertainty regarding the scope of nineteenth-century municipal immunity has its origin in confusion between quasicorporations and incorporated municipalities. See, e.g., Comment, Municipality's Common Law Liability for Police Torts, 1973 WASH. U. L.Q. 908, 908 \& n.5 (indicating that "[a]t early common law municipalities were not liable for torts committed by their employees," but citing cases dealing with quasi-corporations). Many nineteenth-century courts were themselves aware of the misapplication of the quasi-corporation doctrine. See, e.g., Weightman v. Corporation of Washington, 66 U.S. (1 Black) 39, $52-53$ (1861).

"Cf. Monell, 436 U.S. at 720-21 (Rehnquist, J., dissenting) ("no state court had ever held that municipal corporations were always liable in tort in precisely the same manner as other persons").

" 97 Early nineteenth-century cases held municipalities liable for both public and private activities. See, e.g., Pritchard v. Georgetown, 19 F. Cas. 1348 (C.C.D.C. 1819) (No. 11,437) (municipality liable for damage caused by negligent street repairs); Hooe v. Alexandria, 12 F. Cas. 462 (C.C.D.C. 1802) (No. 6,667) (municipality liable for conduct of street commissioner); Moore v. Mayor of Mobile, 1 Stew. 284 (Ala. 1828) (dictum) (municipality liable as warehouseman); Wallace v. City of Muscatine, 4 Greene 373 (Iowa 1854) (city liable for damage caused by negligent construction of drainage system); Tallahassee v. Fortune, 3 Fla. 19,25 (1850) (municipality liable for trespass on the case); Walling v. Mayor of Shreveport, 5 La. Ann. 660 (1850) (city liable for negligent road construction); Baumgard v. Mayor of New Orleans, 9 La. 119 (1836) (city liable in trespass for illegal seizure of property by carriage inspection commissioner); Mayor of Baltimore v. Marriott, 9 Md. 160, 174 (1856) (when municipality has statutory duty to prevent nuisances, "[a]s the duty is the same in the corporation and the individual, so are the consequences the same for its disregard"); Thayer v. City of Boston, 36 Mass. (19 Pick.) 511, 515 (1837) (dictum) (Shaw, C.J.) ("That an action sounding in tort, will lie against a corporation, though formerly doubted, seems now too well settled to be questioned."); Baker v. City of Boston, 29 Mass. (12 Pick.) 184 (1831) (dictum) (city may be liable for creating a public nuisance if it is negligent in damming a creek and the plaintiff suffers special damage); Hutson v. Mayor of New York, 9 N.Y. 163 (1853) (city liable for personal injuries caused by failure to keep streets in good repair); Mayor of New York v. Bailey, 2 Denio 433, 439 (N.Y. 1845) ("Although it was once doubted whether an action of trespass, or trover, or an action on the case for malfeasance would lie against a corporation, it is now settled in England, as well as in this state that such an action may be 
of tort liability changed somewhat over the course of the century, in 1871 courts in all but two American jurisdictions ${ }^{98}$ still held municipalities liable for torts committed by their employees in the course of a wide variety of municipal activities-those categorized as "proprietary" or "corporate." And municipalities were almost universally held liable for those activities under the principle of respondeat superior. ${ }^{100}$ As Professor Dillon explained in his 1872

maintained against corporations as well as actions upon the case for nonfeasance."); Delmonico v. Mayor of New York, 1 Sand. 222, 225 (Super. Ct. N.Y. 1848) ("the corporation of the city is liable for injuries occasioned by the negligence, unskillfulness or malfeasance of its agents and contractors, engaged in the construction of its public works"); People v. Corporation of Albany, 11 Wend. 539 (N.Y. 1836) (dictum) (individuals can sue municipalities for tort injuries); Meares v. Commissioners of Wilmington, 31 N.C. (9 Ired.) 73, 79 (1848) (Pearson, J.) ("In the United States the liability of corporations to actions of tort is well settled"); City of Dayton v. Pease, 4 Ohio St. 80, 96 (1854) ("We have again and again affirmed, that the liability of corporations, private and municipal, are no less extensive; and that the maxim, respondeat superior, properly applies to them, in the same manner, and to the same extent, as in its application to the liabilities of private individuals."); Town Council of Akron v. McComb, 18 Ohio 229, 230 (1849) ("a municipal corporation is liable for an injury resulting to the property of another, by an act strictly within its corporate powers, and without negligence or malice"); Rhodes v. City of Cleveland, 10 Ohio 160, 162 (1840) ("corporations are liable like individuals, for injuries done, although the act was not beyond their lawful powers"); Commissioners of Kensington v. Wood, $10 \mathrm{~Pa} .93,95-96$ (1848) ("It cannot be controverted, that the [municipality is] liable for any injury arising from the unskilful, improper, insufficient, and inartful manner in which the work is done."); Cole v. Corporation of Nashville, 36 Tenn. (4 Sneed) 162, 164, 166 (1856) (municipality liable for granting apothecary's license to a known "lunatic and insane" person who caused an explosion injuring the plaintiff); Batty v. Town of Duxbury, 24 Vt. 155 (1852) (town primarily liable for injuries caused by obstruction to public highway created by negligence of railroad company and not corrected by the town). But see Monell, 436 U.S. at 721 (Rehnquist, J., dissenting) (citing no nineteenth-century authority).

a See Dunbar v. Alcalde of San Francisco, 1 Cal. 355 (1850) (court, apparently confusing liability rules governing quasi-corporations, see note 95 supra, with those governing actual corporations, found no common-law municipal liability); White v. City Council of Charleston, 20 S.C.L. (2 Hill) 571, 574 (1835) (same). See also Barnett, supra note 95, at 261.

"In 1842, the distinction between "public" and "private" corporate functions was made, in dicta, in a widely followed New York case, Bailey v. Mayor of New York, 3 Hill 531 (Super. Ct. N.Y. 1842), aff'd, 2 Denio 433 (N.Y. 1845). By 1871, the private-public distinction had become accepted doctrine. See T. Coolzy, A Traatise on the Law of ToRTs 619-27 (1880); J. Dillon, Treatise on the LaW of Municipal Corporations § 766, at 723 (1872). The origin of the distinction may lie, in part, in the confusion between nonliable unincorporated governmental units and fully liable municipal corporations. See Barnett, supra note 95, at 266. In some jurisdictions, however, municipalities may have still been held liable for governmental actions in 1871; Arkansas, for example, seems to have adopted the governmental-proprietary distinction in 1872. City of Little Rock v. Willis, 27 Ark. 572, 576 (1872).

${ }_{100}$ See, e.g., Weightman v. Corporation of Washington, 66 U.S. (1 Black) 39, 49 (1861) (court not convinced by argument that municipal corporations "are not responsible for the nonfeasances or misfeasances of the persons necessarily employed by them"); Hooe v. Alexandria, 12 F. Cas. 462 (C.C.D.C. 1802) (No. 6,667); Johnson v. Municipality No. One, 5 La. 
Ann. 100, 100 (1850) (reprinting lower court opinion) ("The liability of municipal corporations for the acts of their agent is, as a general rule, too well settled at this day to be seriously questioned."); Baumgard v. Mayor of New Orleans, 9 La. 119 (1836); Anthony v. Inhabitants of Adams, 42 Mass. (1 Met.) 284, 285 (1840) (Shaw, C.J.) (dictum) ("the . . . employer shall be answerable civiliter for the mismanagement and negligence of the agent employed by him"); Thayer v. City of Boston, 36 Mass. (19 Pick.) 511 (1837) (dictum); City of Detroit v. Corey, 9 Mich. 165, 183-84 (1861) (when city had obligation to barricade sewer excavation, contractors who acted "as agents of the city" made it liable under respondeat superior); Requa v. City of Rochester, 45 N.Y. 129, 136 (1871) (city liable for failure to remedy defect in street because of the negligence of "agents charged with that duty"); Darlington v. City of New York, 31 N.Y. 164, 200 (1865) (dictum) ("public corporations [are] responsible on account of their legal personality, and their capacity for suing and being sued, for the negligent acts of their agents and servants in the execution of their duties"); Delmonico v. Mayor of New York, 1 Sand. 222 (Super. Ct. N.Y. 1848); Meares v. Commissioners of Wilmington, 31 N.C. (9 Ired.) 73, 79 (Pearson, J.) ("the defendants as a corporation . . . are liable for the damage done by their agent, under the rule respondeat superior"); City of Dayton v. Pease, 4 Ohio St. 80, 96 (1854) ("We have again and again affirmed, that the liabilities of corporations, private and municipal, are no less extensive; and that the maxim, respondeat superior, properly applies to them, in the same manner, and to the same extent, as in its application to the liabilities of private individuals."); Goodloe v. City of Cincinnati, 4 Ohio 500 (1831); Cole v. Corporation of Nashville, 36 Tenn. (4 Sneed) 162, 166 (1856) ("The general doctrine is now well established, both in England and this country, that corporations are liable for the wrongful acts and neglect of their officers and agents."). Cf: Boyland v. Mayor of New York, 1 Sand. 27, 30 (Super. Ct. N.Y. 1847) (holding city not liable for gunshot wounds sustained at a public meeting because "[t] he relation of master and servant, or principal and agent, did not exist here, between the corporation, and the person who fired the cannon").

$\ddot{A}$ number of nineteenth-century municipal cases appear, on first glance, to reject respondeat superior. Most of these, however, do not actually reject the view that a municipality is liable for the acts of its employees; rather, they give a narrow interpretation to the doctrine of respondeat superior itself. The reason is that the scope of respondeat superior liability, as applied to both private and municipal corporations, changed somewhat over the course of the eighteenth and nineteenth centuries: employers were at first not held liable for intentional or unlawful actions committed by their employees, even if those actions were undertaken for the benefit of the employer. See, e.g., Prather v. City of Lexington, 52 Ky. (13 B. Mon.) 559, 560 (1852) (dictum) (a municipality is "not responsible for the unauthorized and unlawful acts of its officers, although done under color of their office . . . . [I]t must appear . . . that they were done in pursuance of a general authority to act for the corporation"); Fox v. Northern Liberties, 3 Watts \& Serg. 103, 106 (Pa. 1841) (Where municipal officer seized plaintiff's property wrongfully claiming that plaintiff had violated city ordinances, "it cannot be said that the officer acts under any authority given to him . . . It is like the familiar case of master and servant, where the latter wilfully does an act without the consent or authority of the master, by which a third person is injured, the servant alone is answerable."). But these cases did not require that the employer expressly authorize the tort; rather, the action must have been "done bona fide in pursuance of a general authority to act for the city," Thayer v. City of Boston, 36 Mass. (19 Pick.) 511, 517. (1837). These cases thus took a restrictive view of the "scope of employment" requirement, see note 5 supra. This was not, however, the general view even at the beginning of the nineteenth century. See, e.g., Hooe v. Alexandria, 12 F. Cas. 462 (C.C.D.C. 1802) (No. 6,667) (municipality liable for an employee's wrongs "if he was acting under their authority . . . although he may have acted without their orders, or contrary to them"); Goodloe v. City of Cincinnati, 4 Ohio 500, 513-14 (1831) ("Whatever may have been the ancient doctrines, with regard to the liability of corporations, for wrongs done by their agents, courts have gradually departed from them . . . There is no justice in sending [the plaintiff] to seek redress from an irresponsible agent"). Indeed, beginning in the eighteenth century, courts found a theory of respondeat superior that made 
treatise on municipal corporations, "[w]hen it is sought to render a municipal corporation liable for the acts of a servant or agents, $a$ cardinal inquiry is, whether they are servants or agents of the corporation." 101 If the employee's acts "relate to the exercise of corporate powers, and are for the peculiar benefit of the corporation in its local or special interest, [the employees] may justly be regarded as its

the master liable only for acts commanded by him "far too narrow to meet the expanding complications of commerce and industry," and they therefore began to impose the broader liability rule prevalent today. W. Prosser, supra note $5, \S 69$, at 458-59. Accord, RBstaTEMENT, supra note 5, \& 219, Comment a, at 483.

Other nineteenth-century cases offer a host of obscure doctrines for finding municipalities immune from liability for the acts of their employees, but none of these present a principled rejection of respondeat superior. Some cases, for example, indicate that municipalities cannot be made liable for the discretionary wrongdoing of their agents. See, e.g., Mayor of New York v. Bailey, 2 Denio 433, 450 (N.Y. 1845) (dictum) (opinion of A. Hand, Senator) ("a municipal corporation [is] not liable for acts requiring the exercise of discretion when those acts are for the benefit of the public"); Haynes v. Town of Burlington, $38 \mathrm{Vt} .350,361$ (1865) (dictum) ("We are not prepared to hold that . . . officers in the performance of their official duty, do sustain to the town the ordinary relation of private agents to a principal"). But these cases seem merely to refer to the corporate-governmental distinction-a distinction that has no implications for respondeat superior. See text and notes at notes 103105 infra.

Some cases indicate that public officers should not be held liable for the acts of persons they are obliged to employ in order to discharge a public duty. See, e.g., Bailey v. Mayor of New York, 3 Hill 531, 538 (Sup. Ct. N.Y. 1842), aff'd, 2 Denio 433 (N.Y. 1845). Supervisory officials, however, are never liable for the acts of their subordinates under respondeat superior. See text and note at note 66 supra.

Finally, at least one case suggested that municipalities could only be liable when negligent in carrying out a legal duty to maintain a public work; according to the court it was only in this type of case that the servant had no discretion. Elliott v. City of Philadelphia, $75 \mathrm{~Pa}$. 347, 349-50 (1874) (reprinting lower court opinion). While it is true that many nineteenth-century cases dealing with municipalities involve negligence relating to public works, or failure to perform a legal duty-perhaps because nineteenth-century municipalities had relatively few employees and were therefore subjected to fewer suits based upon a respondeat superior theory, or because the construction and maintenance of public works was the most common form of "corporate" activity-Elliott appears to misstate the law. A substantial number of nineteenth-century cases did hold municipalities liable for the general torts of their employees. See, e.g., Baumgard v. Mayor of New Orleans, 9 La. 119 (1836); Cole v. Corporation of Nashville, 36 Tenn. (4 Sneed) 162 (1856). And the cases explicitly recognized that municipalities could be made liable for the acts of agents committed in the course of their regular duties as well as for negligence in the construction of public works. See, e.g., Prather v. City of Lexington, $52 \mathrm{Ky}$. (13 B. Mon.) 559, 560-61 (1852) (dictum). The Elliott court may have been confused by the ultra vires doctrine, which protected municipalities from liability for actions taken outside "the general powers of the corporation." C. ELLIOTT, The Principles of the Law of Public Corporations $\$ 302$, at 271 (1898). Cf. Mayor of Albany v. Cunliff, 2 N.Y. 165 (1849) (where city lacked authority to construct a bridge because the enabling legislation was not passed by a two-thirds majority, the city would not be liable for negligent construction).

101 J. DrLLoN, supra note $99, \$ 772$, at 730 (emphasis in original). 
agents or servants, and the maxim of respondeat superior applies."102

It is true that in 1871 municipalities enjoyed a limited protection from liability for the torts of their employees. This protection was based on the fiction that there is a distinction between the municipality's corporate actions-for which it was liable-and its "public" or "governmental" activities-for which it was not. But this was not seen as an immunity as such; rather, as Dillon explained, municipal agents who engaged in governmental activities were "not to be regarded as the servants or agents of the corporation . . . but as public or state officers." 103 The rationale was that the delivery of "public" services, such as police protection, was the duty of the state. The municipality was immune, then, not because the principle of respondeat superior was abandoned in some areas, but because, under the private-public distinction, the agent was seen as the employee of the state rather than of the municipality. ${ }^{104}$ The municipality merely supervised the employee on behalf of the state, and as a supervisor was not liable under respondeat superior; ${ }^{105}$ the state presumably would have been liable had it not been protected by sovereign immunity.

Respondeat superior liability for municipalities was therefore the rule and not the exception when Congress enacted section 1983; insofar as municipalities were liable, it was under that principle. And the theory that governed municipal liability was considered identical to the one that controlled the liability of private corporations. ${ }^{108}$ Thus, if Congress intended to impose liability on municipal

${ }^{102} I d$. (emphasis in original). And the doctrine was applied to municipalities precisely as it was applied to other corporate bodies. T. Cooley, supra note 99, at 122 . Accord, C.

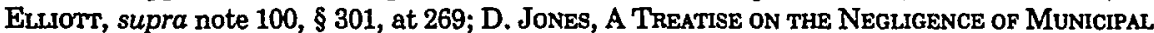
CoRPorations $\S 161$, at 312-13 (1892). But see E. JAGgARD, supra note 66 at 173, 181 (while a municipality is liable for the proprietary acts of its agents, it is not liable unless it has authorized or ratified them).

16 J. Dillon, supra note 99,8772 , at 730 .

104 For example, firemen and police officers were considered officers of the state rather than of the municipality. See id. $\$ \S 773-774$, at $732-34$.

tos See note 66 supra.

106 See, e.g., Hooe v. Alexandria, 12 F. Cas. 462 (C.C.D.C. 1802) (No. 6,667) (municipality treated like private corporation); Moore v. Mayor of Mobile, 1 Stew. 284 (Ala. 1828) (dictum) (municipality liable as a warehouseman); McKim v. Odom, 3 Bland 407, 417, 419 (Md. Ch. 1828) (dictum) ("The right and capacity to sue and be sued, is an incident to bodies politic of all descriptions," including those which "relate merely to the public police" which are "the auxiliaries of the government in the great business of municipal rule"); Thayer $v$. City of Boston, 36 Mass. (19 Pick.) 511, 516 (1837) ("there seems no sufficient ground for a distinction in this respect [liability], between cities and towns and other corporations"); Mayor of New York v. Bailey, 2 Denio 433 (N.Y. 1845) (municipality treated like private corporation); Meares v. Commissioners of Wilmington, 31 N.C. (9 Ired.) 73, 80 (1848) (court responded to municipality's attempt to distinguish municipal and private corporations by noting that " $[t]$ his distinction . . . appears at the first suggestion to be plausible, but will 
corporations under the statute, as the Monell Court held, it is likely that such liability was seen as following the only model of municipal liability with which most legislators were familiar-respondeat superior. It has been said that if Congress had intended to create municipal liability under section 1983, that intention would have been reflected in the legislative debates. ${ }^{107}$ It seems more accurate to say that had Congress intended to change the law by eliminating municipal respondeat superior, that intention would have been clearly reflected in the legislative history.

It can be argued, of course, that the distinction between public and private acts should continue to be applied in suits against municipalities. Municipalities would then be held liable only for the acts of those who, in 1871, would have been considered municipal rather than state employees. Such an approach should, however, be rejected. The common law of 1871 undoubtedly sheds light on whether Congress contemplated respondeat superior liability in enacting section 1983. But in a series of recent cases dealing with immunities under that statute, the Supreme Court has indicated that when construing section 1983, both the statutory purpose and developments in the common law since 1871 must be considered in addition to the tort-law background against which Congress was legislating. ${ }^{108}$ Most importantly, the Court has indicated that an interpretation that would defeat the statutory purpose cannot stand.

Adoption of the private-public fiction would frustrate both of the goals of section 1983-the compensation of victims and the deterrence of official misconduct. ${ }^{109} \mathrm{By}$ creating immunity for certain municipal actions labeled "public," a vacuum would be created in areas in which section 1983's remedial effect is most often needed. Police services, for example, were traditionally considered to be "public,"110 but there is a tremendous potential for the abuse of policy authority-and it was the abuse of official authority that prompted the enactment of section 1983.111

not bear examination, and is more fanciful than real"); City of Dayton v. Pease, 4 Ohio St. 80,95 (1854) ("we have again and again affirmed, that the liabilities of corporations, private and municipal, are no less extensive"); McCombs v. Town Council of Akron, 15 Ohio 474 (1846) (muncipality treated like private corporation); Rhodes v. City of Cleveland, 10 Ohio 159 (1840) (same); Barnett, supra note 95, at 259.

107 Monell, 436 U.S. at 722 (Rehnquist, J., dissenting).

${ }^{10 s}$ E.g., Imbler v. Pachtman, 424 U.S. 409 (1976); Wood v. Strickland, 420 U.S. 308

(1975); Scheuer v. Rhodes, 416 U.S. 232 (1974).

100 See text and notes at notes 80-89 supra.

"16 See note 104 supra.

II' See, e.g., Mitchum v. Foster, 407 U.S. 225, 242 (1972) ("The very purpose of $\S 1983$ 
At the same time, the private-public distinction has never produced a coherent body of case law, and most commentators have concluded that it is impossible to reach principled decisions on the basis of the distinction. ${ }^{112}$ Many jurisdictions have therefore moved away from its use. ${ }^{113}$ This, too, counsels against adoption of the distinction in section 1983 cases.

Both of the traditional sources of authority to which the courts have looked in construing section 1983 thus support the imposition of respondeat superior liability on municipalities. In the absence of any persuasive countervailing argument, then, it seems that respondeat superior should be applied to municipalities to vindicate constitutional rights effectively and to fulfill the congressional intent.

\section{Federalism}

The Monell Court did not indicate that principles of federalism militate against section 1983 municipal liability. But in several recent cases, ${ }^{114}$ most notably National League of Cities $v$. Usery, ${ }^{115}$ the

was to interpose the federal courts between the States and the people, as guardians of the people's federal rights"); Santiago v. City of Philadelphia, 435 F. Supp. 136, 148-49 (E.D. $\mathrm{Pa}$. 1977) (section 1983 "is intended by its terms to protect individual rights from abuse by municipalities and other repositories of state power") (footnote omitted).

112 See, e.g., W. Prosser, supra note 5, $\S 131$, at 979; Borchard, Government Liability in Tort (pt. 2), 34 YALE L.J. 129 (1924) ("In few, if any, branches of the law have the courts labored more abjectly under the supposed inexorable domination of formulas, phrases and terminology, with the result that facts have often been tortured into the framework of a formula, lacking in many cases any sound basis of reason or policy.").

113 See, e.g., Marusa v. District of Columbia, 484 F.2d 828 (D.C. Cir. 1973); Scruggs v. Haynes, 252 Cal. App. 2d 256, 60 Cal. Rptr. 355 (1967); Arnolt v. City of Highland Park, 52 Ill. 2d 27, 282 N.E.2d 144 (1972); Andrews v. City of Chicago, 37 Ill. 2d 309, 226 N.E.2d 597 (1967). See also 18 F. McQunLin, Municipal Copporations $\$ 53.02$ (3d ed. 1977); Bermann, Integrating Governmental and Officer Tort Liability, 77 CoLUm. L. Rev. 1175, 1175-78 (1977); Smith, Municipal Tort Liability, 48 Mrch. L. REv. 41 (1949); 7 U. ToL. L. Rev. 624, 628-29 (1976). The federal government has also waived sovereign immunity in this area, and recently permitted liability for certain intentional torts of its employees. Federal Tort Claims Act, 28 U.S.C. $\S 2680$ (h) (1976).

i' E.g., Rizzo v. Goode, 423 U.S. 362, 379-80 (1976); Doran v. Salem Inn, Inc., 422 U.S. 922, 927-28 (1975); Younger v. Harris, 401 U.S. 37, 44-45 (1971).

11526 U.S. 833 (1976). The decision has provoked extensive commentary. See, e.g., Barber, National League of Cities v. Usery: New Meaning for the Tenth Amendment?, 1976 Sup. CT. REv. 161; Kilberg \& Fort, National League of Cities v. Usery: Its Meaning and Impact, 45 Geo. WASH. L. REv. 613 (1977); Schwartz, National League of Cities v. UseryThe Commerce Power and State Sovereignty Redivivus, 46 Fordham L. REv. 1115 (1978); Tribe, Unraveling National League of Cities: The New Federalism and Affirmative Rights to Essential Government Services, 90 HaRv, L. REv. 1065 (1977); Note, Toward New Safeguards on Conditional Spending: Implications of National League of Cities v. Usery, 26 AM. U.L. Rev. 726 (1977); Comment, Constitutional Law-Commerce Power Limited to Preserve States' Role in the Federal System, 30 RutGERs L. REv. 152 (1976); 57 B.U. L. REV. 178 (1977). 
Court has given new life to the concept of federalism ${ }^{116}$ - a principle that guarantees the "separate and independent existence" " of the states ${ }^{117}$ and local governments. ${ }^{118}$ The adoption of respondeat superior liability under section 1983 would likely increase the number of federal suits initiated and successfully prosecuted against municipalities. Such a liability scheme would affect the independence of local governments both by placing demands on municipal treasuries and by influencing local hiring and supervisory decisions. Given this impact on local sovereignty, respondeat superior liability for municipalities under section 1983 is arguably either unconstitutional or, as a matter of statutory interpretation, unintended.

\section{A. The Constitutionality of Respondeat Superior. Liability}

While the Constitution contains few explicit guarantees of state sovereignty, ${ }^{119}$ it plainly assumes the existence of the states as independent entities, which are to be "left free to perform their separate functions in their separate ways." 120 Further, the tenth amendment has been interpreted to mean that "Congress may not exercise power in a fashion that impairs the States' integrity, or their ability to function effectively in a federal system." 121 It is therefore possible to view the imposition of respondeat superior liability, although within an enumerated congressional power, as beyond congressional authority because it would damage the "separate and independent existence" of the states. Such an analysis would rely on National League, in which the Court ruled that provisions of the Fair Labor Standards Act (FLSA), 122 though "undoubtedly within the scope of

II See generally Choper, The Scope of National Power Vis-a-Vis the States: The Dispensability of Judicial Review, 86 YALE L.J. 1552 (1977); Cox, Federalism and Individual Rights Under the Burger Court, 73 Nw. U.L. Rev. 1 (1978); Lay, States' Rights: The Emergence of New Judicial Perspective, 22 S.D. L. REv. 1 (1977); Shapiro, Mr. Justice Rehnquist: A Preliminary View, 90 HaRv. L. Rev. 293, 315-22 (1976); Note, Municipal Bankruptcy, the Tenth Amendment and the New Federalism, 89 Harv. L. REv. 1871 (1976).

117426 U.S. at 845 (quoting Coyle v. Smith, 221 U.S. 559, 580 (1911)).

in 426 U.S. at 855 n. 20 .

119 The eleventh amendment protects the states-albeit not absolutely-from suits in federal courts. U.S. CoNST. amend. XI. But the amendment has been held not to reach political subdivisions of the states. See Lincoln County v. Luning, 133 U.S. 529, 530 (1890). Further, Congress can abrogate the eleventh amendment immunity of the state when implementing the guarantees of the fourteenth amendment. See Fitzpatrick v. Bitzer, 427 U.S. 445, 456 (1976); Field, The Eleventh Amendment and Other Sovereign Immunity Doctrines: Congressional Imposition of Suit Upon the States, 126 U. PA. L. REv. 1203, 1232 \& n.143 (1978).

120 Younger v. Harris, 401 U.S. 37, 44 (1971).

121 Fry v. United States, 421 U.S. 542, 547 n.7 (1975).

12229 U.S.C. $\$ \S 201-219$ (1976). The Act originally excluded government employees from its provisions; the legislation at issue in National League was a 1974 amendment, see 29 U.S.C. $\S 203(d),(x)$ (1976). 
the commerce clause," 123 must be held void as inconsistent with state sovereignty. "If Congress may withdraw from the States the authority to make . . . fundamental employment decisions," wrote Justice Rehnquist for the Court, "we think there would be little left of the States' 'separate and independent existence.' "124 Justice Rehnquist thus drew upon the dual-sovereignty tradition enunciated in cases such as Collector v. Day. ${ }^{125}$

The simplest answer to this argument is that congressional authority for enacting section 1983 is drawn from the fourteenth amendment, which explicitly limits state power and has long been interpreted as granting to Congress unique authority vis-à-vis the states. In Ex parte Virginia, ${ }^{126}$ the Court found that the thirteenth and fourteenth amendments "were intended to be, what they really are, limitations on the power of the States, and enlargements of the power of Congress." 127 Thus the Court concluded that in cases "embraced within the fourteenth amendment," congressional power is "complete,"128 and thereafter the Court has consistently held that when enforcing the amendment's guarantees Congress can overcome what would otherwise be compelling state interests. ${ }^{129}$ Indeed, the National League Court expressly left open the question whether it would have struck down the FLSA amendments had Congress been acting under the fourteenth amendment rather than the commerce clause. ${ }^{130}$

The most recent indication of the unique power of Congress in enforcing the substantive guarantees of the fourteenth amendment is in Monell itself, where the Court flatly declared that National League is "irrelevant" to the consideration of a case involving "a federal-court judgment enforcing the express prohibitions of unlaw-

123426 U.S. at 841.

${ }^{124}$ Id. at 851 (quoting Coyle v. Smith, 221 U.S. 559, 580 (1911)).

12578 U.S. (11 Wall.) 113 (1870). See text and notes at notes $44-48$ supra.

126100 U.S. 339 (1879).

127 Id. at 345 .

${ }^{128}$ Id. at 348.

129 See, e.g., Fitzpatrick v. Bitzer, 427 U.S. 445 (1976). In Fitzpatrick, Justice Rehnquist, writing for the Court, noted-although in the context of the eleventh amendment-that "Congress may, in determining what is 'appropriate legislation' for the purpose of enforcing the provisions of the Fourteenth Amendment, provide for private suits against States or state officials which are constitutionally impermissible in other contexts." Id. at 456 (footnote omitted).

${ }^{130} 426$ U.S. at 852 n.17. The lower federal courts have relied upon the Court's footnote to validate congressional action in other areas. See, e.g., Marshall v. Sheboygan, 577 F.2d 1 (7th Cir. 1978); Usery v. Charleston County School Dist., 558 F.2d 1169 (4th Cir. 1977); Usery v. Allegheny County Inst. Dist., 544 F.2d 148, 155 (3d Cir. 1976). See also Kilberg \& Fort, supra note 115. 
ful state conduct enacted by the Fourteenth Amendment.' "'131 Just such conduct would be involved in a section 1983 suit based on respondeat superior against a municipality. A full application of section 1983 would therefore not overstep congressional authority under the Constitution.

\section{B. The Clear-Statement Rule}

Granted the requisite congressional power, a more plausible argument against respondeat superior may be based on the limits of federal judicial authority. One approach to reconciling federalism concerns with congressional authority in this area is to find that, as a matter of statutory construction, considerations of federalism support an interpretation of section 1983 that does not comprehend municipal respondeat superior liability. The analysis used in this approach is usually formulated as a canon of construction-frequently referred to as the "clear-statement rule"132-that requires ambiguous federal statutes to be interpreted narrowly to avoid impinging upon state sovereignty. While the Supreme Court has not tied the rule to a particular constitutional provision, it apparently draws on both the tenth ${ }^{133}$ and eleventh ${ }^{134}$ amendments. The aim of this approach is to ensure that Congress intended its actions to have an impact on the federal-state balance, and to prevent the courts from usurping Congress's functions. ${ }^{135}$ The potential application of this analysis to the problem here is obvious: since

131 436 U.S. at 690 n.54 (quoting Milliken v. Bradley, 433 U.S. 267, 291 (1977)).

132 See, e.g., United States v. Bass, 404 U.S. 336, 349 (1971) ("unless Congress conveys its purpose clearly, it will not be deemed to have significantly changed the federal-state balance") (footnote omitted).

is See L. Tribe, American Constitutionaz Law 141-42 (1978) (in light of the tenth amendment's guarantee of an effective federal system, "the Supreme Court should not lightly infer serious congressional inroads upon state autonomy"). In extreme cases, where the congressional action will interfere directly with vital state functions, even an absolutely clear statement of congressional purpose will not validate the congressional action. See National League, 426 U.S. at 851-52; Fry v. United States, 421 U.S. 542, 547 n.7 (1975).

The force of the tenth amendment "prong" of the clear-statement analysis is, however, put in some doubt by City of Lafayette v. Louisiana Power \& Light Co., 435 U.S. 389 (1978), in which Justice Brennan, writing for a plurality of the Court, indicated that National League creates no "presumption" in favor of municipalities. Id. at $412 \mathrm{n} .42$; see text and notes at notes 149-152 infra.

I3 See L. TRIBE, supra note 133, at 139-41, 140 \& n.8. This prong of the clear-statement analysis views the eleventh amendment as conferring on the states rights against the federal judiciary, rather than rights against Congress. Thus, the clear-statement rule prevents the courts from developing their own remedies against the states, and as a result is "an appropriate and useful approach to reconciling national power with state litigational immunity." Id. at 141 (footnote omitted).

iss See id. at 139-43. 
section 1983 makes no mention of respondeat superior, perhaps the section should not be read to impose such liability on municipalities. On closer scrutiny, however, it is clear that both the constitutional underpinnings of the clear-statement rule and congressional intent in enacting section 1983 make the approach inapplicable in this context.

The clear-statement rule has not been accorded equal weight in all situations. The Court has insisted that any congressional intent to impinge upon the state litigational immunity conferred by the eleventh amendment be explicit. But it has given the rule less force when considering other statutes that change the federal-state balance in more subtle ways, thereby arguably coming into conflict with the tenth amendment or the guarantees of state sovereignty implicit in the Constitution. Thus, "the more onerous the restriction on state options represented" 136 'by the federal action, the clearer the expression of congressional intent must be. As a result, the clearstatement rule appears to embody a "two-tier" test: one for eleventh amendment cases and one for cases in which more general federalism principles are implicated.

When the statute in question will abrogate eleventh amendment protection, the rule is not easily satisfied. Thus, in Quern $v$. Jordan, ${ }^{137}$ the Court relied on the clear-statement rule to find states excluded from the coverage of section 1983. There, Justice Rehnquist indicated that either express statutory language or a legislative "history focusing directly on the question of state liability"138 is necessary to overcome the "constitutionally guaranteed immunity of the several States,"139 and the Monell holding was distinguished as applying only to nonimmune entities. ${ }^{140}$ The rationale for this stern test is "the importance of the States' traditional sovereign immunity"; 141 that this version of the rule does not include municipalities is shown by Quern's treatment of Monell.

A stronger case, however, can be made for the application here of the "second tier" of the clear-statement analysis. The Supreme Court has indicated that general federalism principles should be

\footnotetext{
136 Id. at 142.

13799 S. Ct. 1139 (1979).

${ }^{138} \mathrm{Id}$. at 1147.

${ }^{139} \mathrm{Id}$. at 1146 (emphasis added) (footnote omitted).

${ }^{140}$ Id. at 1144 ("This Court's holding in Monell was 'limited to local governmental units which are not considered part of the State for Eleventh Amendment purposes" ") (quoting Monell, 436 U.S. at 690 n.54).
}

$1199 \mathrm{~S}$. Ct. at 1146. 
seen as protecting local as well as state governments. ${ }^{142}$ And the second tier $^{143}$ of the clear-statement rule has been invoked outside of the eleventh amendment context whenever the statute would "significantly [change] the federal-state balance."144 Since imposing respondeat superior liability on municipalities could change that balance, the analysis is aguably relevant even when political subdivisions of the states are involved. ${ }^{145}$ Yet two factors militate against the use of the clear-statement analysis in the instant context. First, concerns over federalism are mitigated here because the usual presumption in favor of state and local sovereignty is weak with respect to section 1983. The Civil Rights Act of 1871-from which section 1983 derives-is a unique statute in which Congress, under the authority of the fourteenth amendment, consciously altered the federal-state relationsip in favor of federal power. ${ }^{146}$ Under the Act, the federal courts were interposed "between the States and the people, as guardians of the people's federal rights." 147 Given Monell's holding that section 1983 applies to municipalities, construing the provision narrowly so as to avoid injury to local sovereignty seems particularly inappropriate.

12 See, e.g., National League of Cities v. Usery, 426 U.S. 833,855 n.20 (1976). But see Michelman, States' Rights and States' Roles: Permutations of "Sovereignty" in National League of Cities v. Usery, 86 YALE L.J. 1165, 1170 \& n.20 (1977).

${ }_{143}$ Quern demonstrates that a lesser showing of congressional intent is sufficient when eleventh amendment abrogation is not involved. There the Court indicated that congressional authorization must be apparent before a statute is said to make states amenable to suit. 99 S. Ct. at 1145. No such finding was made in Monell, although the same general legislative history was considered in both Monell and Quern; in Monell it convinced the Court to find municipalities liable, while in Quern the Court declared itself "unwilling to believe . . . that Congress intended by the general language of $\$ 1983$ to override the traditional sovereign immunity of the States." 99 S. Ct. at 1145. Similarly, in Monell the Court was unconvinced by Justice Rehnquist's argument that Congress would have explicitly discussed the question of municipal liability had it wished to hold cities liable, see 436 U.S. at 718-24 (Rehnquist, J., dissenting); in Quern, that argument was a "significant" prop in the majority's reasoning. 99 S. Ct. at 1146.

14 United States v. Bass, 404 U.S. 336, 349 (1971) (footnote omitted). Accord, United States v. Enmons, 410 U.S. 396, 411 (1973); UAW v. Wisconsin Employment Relations Bd., 351 U.S. 266, $274-75$ (1956); United States v. Five Gambling Devices, 346 U.S. 441, 449-50 (1953); FTC v. Bunte Bros., Inc., 312 U.S. 349, 354-55 (1941); Apex Hosiery Co. v. Leader, 310 U.S. 469, 513 (1940); Palmer v. Massachusetts, 308 U.S. 79, 83-84 (1939).

115 For example, what would previously have been a state tort suit against a municipality might become a federal action, so that federal courts would take jurisdiction over what had been an area of the law traditionally reserved to the states. The clear-statement analysis has been applied in an analogous context-rendering an expansive reading to a statute that would federalize what had been state criminal jurisdiction. See, e.g., United States v. Bass, 404 U.S. 336 (1971); United States v. Five Gambling Devices, 346 U.S. 441 (1953).

is See Fitzpatrick v. Bitzer, 427 U.S. 445 (1976).

117 Mitchum v. Foster, 407 U.S. 225, 242 (1972). 
Second, the clear-statement approach has never been given full force in favor of municipalities. ${ }^{148}$ The reasons for this were articulated in City of Lafayette v. Louisiana Power \& Light Co., ${ }^{1+9}$ in which the Court considered whether municipalities should be subject to the antitrust laws. ${ }^{150}$ There, Justice Brennan, writing for a plurality of the Court, stated that "[c]ities are not themselves sovereign; they do not receive all the federal deference of the States that create them." 151 Then, apparently addressing the clearstatement rule, Justice Brennan wrote: "we search in vain for anything in [National League] that establishes a constructional principle of presumptive congressional deference in behalf of cities."152 The municipalities were therefore held liable under the antitrust laws, except insofar as their activities were directed-by the state.

Finally, even if the clear-statement rule applied in full to section 1983 suits against municipalities, it would not seem to compel the rejection of respondeat superior liability for local governments. The Supreme Court has indicated that for cases in which eleventh amendment concerns are not present, an explicit statement of congressional intent to affect the federal-state balance is not necessary. ${ }^{153}$ In these second-tier cases, the clear-statement rule seems to

148 No cases have been found dealing with the exercise of federal power against municipalities in which the Supreme Court invoked the clear-statement rule.

14435 U.S. 389 (1978).

${ }^{130}$ At issue was the scope of Parker v. Brown, 317 U.S. 341 (1943), in which the Court held that states could engage in anticompetitive activities as an act of government. Complicating the decision in Lafayette, however, was the fact that a municipality had already been held to be a "person" under section eight of the Sherman Act, 15 U.S.C. $\$ 7$ (1976), for the purpose of bringing suit as a plaintiff to enforce the antitrust laws, Chattanooga Foundry \& Pipe Works v. Atlanta, 203 U.S. 390 (1906). The Lafayette inquiry thus parallelled that in Parker, in which the Court held states exempt from antitrust regulation though they, too, could bring suit under the antitrust laws.

131435 U.S. at 412.

${ }^{552}$ Id. at 412 n.42. In reaching this conclusion, Justice Brennan relied on cases holding that municipalities are unprotected by the eleventh amendment. Id. Justice Stewart, in dissent, labeled those cases "basically irrelevant," id. at 431 (Stewart, J., dissenting); he argued instead that National League, in holding that municipalities were protected by federalism principles, had established that "states and their political subdivisions must be given equal deference." Id. at 430 . But eleventh amendment jurisprudence may be relevant here. The plurality appears to argue that deference is due the states only because they are "sovereign." Thus, the clear-statement approach is used because, under "our "dual system of government ... the states are sovereign, save only as Congress may constitutionally subtract from their authority." "Id. at 412 (quoting Parker v. Brown, 317 U.S. 341, 351 (1943)). That is the reason "a congressional purpose to . . . control the States' acts of government will not lightly be inferred." Id. Since municipalities are not, even under National League, considered sovereign, following the approach of the City of Lafayette plurality would mean that the clear-statement rule should never be invoked in favor of municipalities, except insofar as they are acting at the behest of the state.

${ }^{153}$ These cases therefore differ from eleventh amendment suits like Quern, in which the 
be merely a canon of construction to be applied when the usual methods of statutory interpretation do not reveal the congressional intent. In Monell, for example, the Court made the threshold determination that municipalities are covered by section 1983 , though there was no suggestion in the opinion that the legislative debates focused on the statute's applicability to municipalities; indeed, as Justice Rehnquist's Monell dissent makes clear, the debates did not directly touch on the question of municipal liability at all. ${ }^{154}$ Nonetheless, the majority and dissent made no mention of the clearstatement rule.

Applying the clear-statement analysis as so formulated to the question of section 1983 municipal liability seems to permit the imposition of respondeat superior. For the common understanding of the scope of municipal liability at the time the statute was enacted, ${ }^{155}$ combined with Congress's intention that the provision be accorded the broadest possible remedial application, ${ }^{156}$ make it

Court insisted on an explicit consideration of state liability in the statutory language or legislative history. $99 \mathrm{~S}$. Ct. at 1139,1146 . Outside the eleventh amendment context, the Court has not considered the rule determinative; it has imposed liability on municipalities without mentioning the clear-statement rule-as it did in Monell-so long as the legislative intent can be derived from the statutory background and purposes. And even in those cases in which the Court has invoked the rule, it has liberally considered both the language and the legislative history -and found that both were either ambiguous or actually favored a narrow interpretation. See, e.g., United States v. Enmons, 410 U.S. 396, 401 (1973) ("The legislative framework" dispels statutory ambiguity); United States v. Bass, 404 U.S. 336, $339,346-47$ (1971) (statutory language "does not read well under either view" and legislative history is "inconclusive"); Rewis v. United States, 401 U.S. 808, 812 (1971) ("neither statutory language nor legislative history" supports a broad statutory construction); Apex Hosiery Co. v. Leader, 310 U.S. 469, 513 (1940) (an interpretation of the Sherman Act resulting from a broad statutory construction was "plainly not intended"); Palmer v. Massachusetts, 308 U.S. 79, 86 (1939) (the "historic background . . . considerations governing Congress . . . and the scheme of the legislation" all militated against a broad statutory interpretation). These cases imply that the clear-statement rule should not be applied so long as the legislative intent can be ascertained-even if that intent is not expressed explicitly.

Similarly, the Court has indicated that the clear-statement rule should not be invoked when doing so would defeat the statutory purpose. See, e.g., FTC v. Bunte Bros., Inc., 312 U.S. 349, 351 (1941) (courts should not read into section 5 of the Federal Trade Commission Act anything "beyond the obvious meaning of language unless otherwise the purpose of the Act would be defeated") (citation omitted). In the context of suits against municipalities, the purposes of section 1983 can be achieved most effectively through respondeat superior. See text and notes at notes 80-89 supra.

In a series of lower court cases, courts have considered the impact of federalism principles on direct constitutional Bivens-type actions against municipalities and have indicated that the clear-statement rule establishes a presumption against judicial activism in the absence of any congressional guidance. See, e.g., Molina v. Richardson, 578 F.2d 846, 852-53 (9th Cir.), cert. denied, 439 U.S. 1048 (1978); Kostka v. Hogg, 560 F.2d 37, 44 n.6 (1st Cir. 1977).

154436 U.S. at 722 (Rehnquist, J., dissenting).

iss See text and notes at notes 95-106 supra.

ist See text and notes at notes 76-77 supra. 
"difficult to conceive of Congress declining to hold cities to a commonplace rule of law such as the rule of respondeat superior." 157

\section{Conclusion}

The Monell Court rejected respondeat superior because of the language and legislative history of section 1983. But its restrictive reading of the statutory language runs counter to the traditionally broad construction accorded the Civil Rights Acts. And by relying on the rejection of the Sherman amendment, the Court simply repeated the mistake for which it rightly condemned the decision in Monroe v. Pape. At the same time, the Court disregarded those factors traditionally used in the interpretation of section 1983: the statutory purpose and the background of nineteenth-century tort law.

The Monell decision markedly increased the number of cases that can be brought under section 1983; the Court may have hoped to modify the decision's impact by adding a bar to respondeat superior. By doing so, however, the Court-in one of the most significant civil rights decisions of the decade-threw into confusion both the ultimate purposes of the statute and the proper methods of statutory interpretation. Before the Monell dictum becomes the basis for future decisions, the Court should reconsider the issue with an eye toward maintaining consistency in this area of the law.

Charles A. Rothfeld

157 Levin, supra note 13 , at 1535. 